\title{
A Closer Look at the Phillips \\ Curve Using State Level Data
}

Anil Kumarand Pia Orrenius

Federal Reserve Bank of Da llas

Research Department

Working Paper 1409 


\title{
A Closer Look at the Phillips Curve Using State-Level Data*
}

\author{
Anil Kumar \\ Research Department \\ Federal Reserve Bank of Dallas \\ 2200 N. Pearl St. \\ Dallas, TX 75201 \\ anil.kumar@dal.frb.org \\ Pia Orrenius \\ Research Department \\ Federal Reserve Bank of Dallas \\ 2200 N. Pearl St. \\ Dallas, TX 75201 \\ pia.orrenius@dal.frb.org
}

May, 2015

\begin{abstract}
Studies that estimate the Phillips curve for the U.S. use mainly national-level data and find mixed evidence of nonlinearity, with some recent studies either rejecting nonlinearity or estimating only modest convexity. In addition, most studies do not make a distinction between the relative impacts of short-term vs. long-term unemployment on wage inflation. Using statelevel data from 1982 to 2013, we find strong evidence that the wage-price Phillips curve is nonlinear and convex; declines in the unemployment rate below the average unemployment rate exert significantly higher wage pressure than changes in the unemployment rate above the historical average. We also find that the short-term unemployment rate has a strong relationship with both average and median wage growth, while the long-term unemployment rate appears to only influence median wage growth.
\end{abstract}

Keywords: Phillips curve, monetary policy, unemployment, inflation, wage growth JEL Classification: E52, E58

\footnotetext{
*We thank Evan Koenig, Mark Wynne, Carlos Zarazaga and participants of the Dallas Fed policy seminar series for helpful comments and suggestions. We also thank Sarah Greer for excellent research assistance. The views expressed here are those of the authors and do not necessarily reflect those of the Federal Reserve Bank of Dallas or the Federal Reserve System.
} 


\section{A Closer Look at the Phillips Curve Using State-Level Data}

\section{Introduction}

Economists have long posited that the Phillips curve may be nonlinear and convex and that inflation may respond asymmetrically to declines in unemployment above versus below the natural rate of unemployment. Nevertheless, a linear Phillips curve remained the standard specification in the vast majority of studies until the 1990's when a series of papers found strong evidence of a convex relationship between inflation and unemployment. ${ }^{1}$ A nonlinear Phillips curve can have starkly different policy implications than those of a linear Phillips curve. While a linear Phillips curve warrants a symmetric monetary policy response with respect to business cycle conditions of excess demand or excess supply, a nonlinear Phillips curve may imply preemptive measures are needed to counter inflation when, for example, the unemployment rate declines below the natural rate. Allowing excess demand conditions to persist may necessitate significant subsequent tightening to curtail inflation, adversely affecting not just actual but also potential output (Laxton et al., 1995; Laxton et al., 1999).

Despite the importance of estimating nonlinear wage-price Phillips curves, most studies focus on price inflation rather than wage inflation, use mainly national-level time-series data and find mixed evidence on nonlinearity, with some recent papers either rejecting nonlinearity or estimating only modest convexity. ${ }^{2}$ Variation in national data on inflation and unemployment may be too limited to yield robust and statistically significant estimates of nonlinearity in the Phillips curve (Coen et al., 1999). Meanwhile, much of the Phillips curve research using regional

\footnotetext{
${ }^{1}$ See for example, Akerlof et al. (1996), Clark et al. (1996), Laxton et al. (1995), Clark and Laxton (1997), Debelle and Laxton (1997), Laxton et al. (1999), Tambakis (1999), Turner (1995), Filardo (1998), Schaling (2004), Barnes and Olivei (2003), Huh et al. (2009), and Fuhrer et al. (2012).

${ }^{2}$ See for example, Gordon (1997), Dupasquier and Ricketts (1998), Eliasson (2001), Tambakis (2009), Ball and Mazumder (2011). Eisner (1997) and Stiglitz (1997) are exceptions that find evidence of a concave Phillips curve.
} 
data has sidestepped nonlinearity and instead focused on heterogeneity across regions, states’ monetary policy responses (Carlino and DeFina, 1998; Carlino and DeFina, 1999), or the stability of a linear Phillips curve (Fitzgerald and Nicolini, 2013). ${ }^{3}$

Following Blanchflower and Oswald (1994), a separate but related strand of the literature uses household-level micro data and regresses the level of nominal wages on their first lag and the local unemployment rate to estimate the "wage curve”. In such specifications, a small or insignificant coefficient on lagged nominal wages can be interpreted as the rejection of a traditional Phillips curve model that involves a regression of nominal wage inflation on lagged price inflation and the unemployment rate. ${ }^{4}$ Using annual data from the March CPS and finding lack of autoregression in the estimated wage curve, Blanchflower and Oswald (1994) rejected the traditional Phillips curve. Using micro and state level data and alternative measure of wages, subsequent papers, however, have challenged the Blanchflower and Oswald (1994) findings and concluded that the traditional Phillips curve is still very relevant (Blanchard and Katz, 1996;, Blanchard and Katz, 1999; Card, 1995; Whelan, 1997). With a few exceptions, the wage curve literature also largely focuses on the linear effects of the local unemployment rate. ${ }^{5}$

Most previous estimates of the standard linear Phillips curve also have not distinguished between the relative impacts on wage inflation of short-term versus long-term unemployment. There is an ongoing debate about whether the long-term unemployed continue to matter for wage inflation. Under the assumption that the Phillips Curve accurately captures the relationship

\footnotetext{
${ }^{3}$ Martínez-García and Wynne (2014) estimate the linear Phillips Curve using city-level data but do not explore nonlinearity.

${ }^{4}$ See Blanchard and Katz (1999) and Whelan (1997) for the relationship between the wage curve and the standard Phillips curve.

${ }^{5}$ Bratsberg and Turunen (1996) estimated a model of the wage curve with a cubic in the local unemployment rate using NLSY data from 1979 to 1993 and found evidence of convexity in unemployment and the log wage relationship. Blanchflower and Oswald (2005) estimated wage curve versions with log of unemployment rate to introduce nonlinearity using CPS-ORG data from 1979 to 2001. See Nijkamp and Poot (2005) for a comprehensive review.
} 
between wages and unemployment, a weak or nonexistent relationship between the long-term unemployment rate and wage inflation would suggest that a substantial number of the long-term unemployed are effectively out of the labor force and out of reach of employers. ${ }^{6}$ Improvements in short-term unemployment could, therefore, generate higher wage pressures than that suggested by changes in the headline rate. In this case, monetary policymakers would need to adjust interest rates sooner to curtail inflation. On the other hand, if the long-term unemployed continue to matter for wage inflation, then an elevated long-term unemployment rate would help keep inflation in check, putting off eventual interest rate hikes. ${ }^{7}$

We make three contributions to the existing literature on nonlinear Phillips curves in the U.S. case. First, unlike previous research that primarily estimates time-series models using national data, we estimate nonlinear specifications of the wage-price Phillips curve using statelevel panel data which has rich variation in wage inflation and unemployment rates. Our paper is different from some papers estimating nonlinear models in the wage curve literature-e.g. Bratsberg and Turunen (1996) and Blanchflower and Oswald (2005)—in that we estimate a traditional wage-price Phillips curve, use more recent data, and consider alternative wage measures. Additionally, we examine the sensitivity of the wage-price Phillips curve estimates to different data frequencies and evaluate the ability of standard Phillips curve models to forecast real wage growth. Second, using quarterly data, we estimate wage-price Phillips curve separately for each state and show that there is substantial heterogeneity in the curve's slope and shape across states. Third, we contribute to an emerging literature that allows the response of real wage inflation to vary by the type of labor market slack. We estimate Phillips curve specifications that

\footnotetext{
${ }^{6}$ See Krueger et al. (2014), Aaronson and Jordan (2014), Smith (2014), Kiley (2014), Linder et al. (2014) for U.S. evidence and Llaudes (2005) for Europe.

${ }^{7}$ An important caveat to this interpretation in the context of this paper is that the measure of wages used in estimated wage-price Phillips curve models excludes fringe benefits and other non-pecuniary aspects of employment.
} 
distinguish between the relative wage growth impacts of short-term vs. long-term unemployment.

Our analysis of state-level data from1982 to 2013 yields four main findings. First, the Phillips curve is nonlinear and strongly convex and unemployment rate declines below the historical average unemployment rate exert significantly higher wage pressures than declines at above-average unemployment rates. Our choice of a specific knot—the average unemployment rate in our sample - for the piecewise-linear specification of the Phillips curve that we estimate, may be somewhat arbitrary. We therefore test nonlinearity in the Phillips curve along a range of unemployment rates on either side of the average rate and come to the same conclusion—the Phillips curve using state-level data is nonlinear and strongly convex. Second, using quarterly data, we uncover substantial heterogeneity in the slope and shape of the Phillips curve across states. Third, in evaluating the out-of-sample predictive ability of our estimated models using state-level panel data, we find — consistent with previous research on inflation forecasting — that the Phillips curve specification does not significantly improve upon forecasts obtained from simple autoregressive models of real wage growth. However, unlike previous research, we find that Phillips curve-based forecasts outperform naïve random walk forecasts of real wage growth. Using state-level data from1994 to 2013, our fourth main finding is that short-term unemployment has a strong relationship with inflation in both average and median wages, but long-term unemployment appears to be significantly associated only with inflation in median wages.

The remainder of the paper is organized as follows. We start with the theoretical motivation for our research in section 2. Section 3 describes the econometric specification and section 4 discusses the data. Section 5 presents the results for the nonlinear Phillips curve and 
associated robustness checks. State-specific estimates of the Phillips curve are presented in section 6. Section 7 discusses results from a forecast evaluation exercise, while section 8 reviews the findings on the differential wage effects of long- and short-term unemployment. Finally, there is a brief conclusion.

\section{Theoretical Motivation}

There are several potential explanations for nonlinearities in the Phillips curve. ${ }^{8}$ First, nominal wages may be downwardly rigid as employers avoid cutting wages even when the unemployment rate is high (Akerlof et al., 1996). On the other hand, wages tend to rise when the economy is booming and the unemployment rate is low. Another explanation for a convex Phillips curve offered by Ball and Mankiw (1994) applies only if the trend inflation is positive. In this case, firms do not need to lower prices when the unemployment rate is high and there is a negative shock to their desired price, they can simply allow inflation to lower relative prices. On the other hand, positive shocks to firms' desired prices (when the unemployment rate is low) are more likely to generate price increases to bridge the gap between increased desired prices and lower actual prices. Capacity constraints could also generate convexity in the Phillips curve if firms struggle to keep up with demand in the short run as the unemployment rate drops below the natural rate.

Shapiro and Stiglitz (1984) provide another explanation for nonlinearity in the Phillips curve. Workers are less likely to shirk if unemployment is high (as job search is more expensive) or if wages are high (as the opportunity cost of shirking is high). Thus, workers' shirking costs

\footnotetext{
${ }^{8}$ See Dupasquier and Ricketts (1998) for detailed analysis of various potential explanations for nonlinearity in the Phillips curve.
} 
are increasing in both unemployment and wages. If this relationship holds true then a decline in unemployment would lower workers’ shirking costs and entail closer monitoring by firms. As an alternative, firms may use wage increases to offset the unemployment-induced decline in shirking costs and avoid costly monitoring. On the other hand, an increase in unemployment would raise shirking costs, alleviating the need for firms to use wages as inducement to contain shirking.

Finally, imperfect competition is also a possible explanation for a nonlinear Phillips curve, although in this case, the curve would be concave. Stiglitz (1997) suggested that in the presence of monopolistic competition, firms may be tempted to lower prices and undercut rivals when the economy slows but not to increase prices when excess demand conditions emerge. The likely net effect of all these factors is that wages and prices may respond asymmetrically to changes in unemployment and the Phillips Curve may be nonlinear and convex.

\section{Econometric Specification}

We estimate a version of the wage-price Phillips curve that stems from a two-equation system of demand and supply wage equations discussed in Blanchard and Katz (1996). Let $w_{t}$ and $p_{t}$ be the natural logarithms of wages and prices, respectively, at time $t$. Let $\Delta w_{t}=w_{t}-w_{t-1}$ be the nominal wage growth. In this model, wages are set such that nominal wage growth $\left(\Delta w_{t}\right)$ depends on expected price inflation $\left(\Delta p_{t}^{e}\right)$, the unemployment rate $\left(u_{t}\right)$, and productivity growth $\left(\Delta x_{t}\right) \cdot{ }^{9}$. If inflation expectations are backward looking, then $\Delta p_{t}^{e}$, can be approximated by the lagged price inflation $\left(\Delta p_{t-1}\right)$ and, therefore, expected real wage growth $\Delta w_{t}-\Delta p_{t}^{\mathrm{e}}$ can be

\footnotetext{
${ }^{9}$ See e.g. page 60 of the JEP article by Blanchard and Katz (1996). See also Katz and Krueger (1996) and Ball and Moffitt (2001).
} 
represented by $\Delta w_{t}-\Delta p_{t-1}$. The intuition that the expected real wage growth should be positively correlated with productivity growth and negatively with the unemployment rate gives rise to the wage-price Phillips curve widely used in the previous literature. ${ }^{10}$ Using state-level data and letting $s$ index states, we can write the wage-price Phillips curve as:

$$
\Delta w_{s t}-\Delta p_{s t-1}=\alpha+\Delta x_{t}+\beta u_{s t}+\epsilon_{s t}
$$

$\epsilon_{s t}$ is an idiosyncratic error term that, conditional on other regressors, must satisfy standard conditions for consistency of the linear regression model. Productivity growth $\Delta x_{t}$ can be subsumed into the time fixed effect $\mu_{\mathrm{t}}$, and we can estimate: ${ }^{11}$

$$
\Delta w_{s t}-\Delta p_{s t-1}=\alpha+\beta u_{s t}+\mu_{\mathrm{t}}+\epsilon_{s t}
$$

Noting that $\Delta w_{s t}-\Delta p_{s t-1}$ is the nominal wage growth adjusted for one period lagged price inflation, we refer to it as the real wage growth in the remainder of the paper and, for notational simplicity, denote it $\Delta w_{s t}^{R}$. In order to use only within-state cross-time variation in the unemployment rate for better identification of $\beta$, we estimate specifications with state fixed effects. $^{12}$

$$
\Delta w_{s t}^{R}=\alpha+\beta u_{s t}+\kappa_{s}+\mu_{\mathrm{t}}+\epsilon_{s t}
$$

Previous research has suggested that changes in unemployment may have an asymmetric effect on wages and the Phillips curve may be nonlinear. To explore nonlinearities between unemployment and wages, we introduce a kink in the Phillips curve around the average

\footnotetext{
${ }^{10}$ See Whelan (1997) for related discussion.

${ }^{11}$ Inclusion of time effects may not fully capture the effect of productivity growth if it varies across states. Therefore, we estimate specifications that also control for state-specific time trends. We acknowledge that even state-specific linear time trends may not fully account for cross-state differential trends in productivity growth if trends are nonlinear.

${ }^{12}$ Note that state fixed effects will be particularly useful if expected inflation is constant over time but varies across regions or states.
} 
unemployment rate and modify (3) to include a linear spline with one knot at $\bar{u}$, the unweighted long-term average unemployment rate of 6.1 percent in the state-level data we use: ${ }^{13}$

$$
\Delta w_{s t}^{R}=\alpha+\beta_{1} u_{s t}+\beta_{2} \max \left(0, u_{s t}-\bar{u}\right)+\kappa_{s}+\mu_{\mathrm{t}}+\epsilon_{s t}
$$

Equation (4) allows the slope of the Phillips curve to differ when $u_{s t}>\bar{u}$. The estimated Phillips curve will be downward sloping and convex if $\beta_{1}<0$ and $\beta_{2}>0$. $^{14}$

Since a linear spline specification with just one knot may be overly restrictive, we also estimate a restricted-cubic spline (natural spline) model with three knots. ${ }^{15}$ Restricted cubic splines with three knots would let the curve be linear before the first knot and after the third knot, while using a cubic polynomial to approximate the curve between the remaining interior knots. Due to these restrictions, the restricted cubic spline model with three knots involves including just one more term to the linear model in (3). Since the linear model is nested within both the linear spline specification as well as the restricted cubit spline model, nonlinearity is conveniently tested using a simple t-test on the significance of the spline term.

The standard wage-price Phillips curve specification in (3) does not distinguish between the effect of long-term unemployment (LTU) and short-term unemployment (STU) on wage

\footnotetext{
${ }^{13}$ The spline specification used here is not new; previous studies have used national time-series data to model nonlinearity in the Phillips curve. Clark et al. (1996) included a kink in the Phillips curve for the positive output gap. Barnes and Olivei (2003) included multiple kinks for a range of unemployment rates. Laxton et al. (1995) also estimated a piecewise-linear Phillips curve with a kink at the positive output gap.

${ }^{14}$ Some authors, e.g. Clark and Laxton (1997), Debelle and Laxton (1997), Laxton et al. (1999), and Tambakis (1999), have proposed convex Phillips curves of the form $\Delta w_{s t}=\alpha+\Delta p_{s t-1}+\beta_{1} \frac{\left(u_{t}^{*}-u_{s t}\right)}{\left(u_{s t}-\phi\right)}+\kappa_{s}+\mu_{t}+\epsilon_{s t}$. Their proposed specification has several appealing properties. However, we do not follow this approach as it imposes stronger functional form restrictions than a flexible spline specification. In their specification, the slope of the Phillips curve equals $-\beta_{1} \frac{\left(u_{t}^{*}-\phi\right)}{\left(u_{t}-\phi\right)^{2}}$, is negative, and depends on $u_{t}^{*}, u_{t}$, and $\phi$. The slope varies with the level of unemployment rate relative to the natural rate of unemployment. There is also a lower bound on the feasible level of the unemployment rate as it cannot go below $\phi$. Third, there is also a lower bound of $-\beta_{1}$ on the extent of deflation. And finally, the slope of the Phillips curve or the inflation-unemployment tradeoff is decreasing in the unemployment rate. The tradeoff is steep for unemployment rate declines significantly below the natural rate as a small decline in unemployment can trigger a disproportionately large increase in inflation. On the other hand, when unemployment is high, a decline in the unemployment rate entails a small rise in inflation.

${ }^{15}$ See Dupont and Dupont (2009) for a description of restricted cubic spline models and their implementation using STATA.
} 
pressures. To examine differential responses of wage inflation to changes in long-term and shortterm unemployment rates, we estimate a Phillips curve specification where the effect of the unemployment rate is decomposed into long-term and short-term measures.

$$
\Delta w_{s t}^{R}=\alpha+\gamma_{1} L T U_{s t}+\gamma_{2} S T U_{s t}+\kappa_{s}+\mu_{\mathrm{t}}+\epsilon_{s t}
$$

We check the sensitivity of our baseline estimates of equations (3), (4), and (5) by conducting a variety of robustness and specification tests.

\section{Data}

We use multiple sources of BLS data to estimate the Phillips curve. Since a time-series of state-level CPI data is not available, we calculate price inflation by using CPI-U data by Census region. We also check the robustness of our baseline estimates to adjusting wage inflation using regional core CPI and 1-year-ahead inflation expectations from the Survey of Professional Forecasters (SPF), which is available from the Federal Reserve Bank of Philadelphia. The state unemployment rates are calculated from the monthly Current Population Survey (CPS or household survey). We use four measures of state-level wages: (1) Average hourly wage rates calculated from the monthly CPS outgoing rotation groups ${ }^{16}(2)$ Median hourly wage rates calculated from the monthly CPS outgoing rotation groups; (3) Average hourly earnings for production workers in manufacturing from the monthly Current Employment Statistics (CES or payroll survey); and (4), Average weekly wages from the Quarterly Census of Employment and Wages (QCEW).

State-level short-term unemployment is defined as those unemployed 26 weeks or less as a percent of the labor force and is calculated from basic monthly CPS from 1994 to 2013. State-

\footnotetext{
${ }^{16}$ CEPR uniform extract of CPS-ORG data were used for analysis (CEPR, n.d.). Appropriate CPS sampling weights were used for calculating average hourly wage rates using CPS-ORG data. Average hourly wage measures appropriately account for top-coding; see Schmitt (2003).
} 
level long-term unemployment is similarly obtained and defined as those unemployed more than 26 weeks as a percent of the labor force. We do not use short-term and long-term unemployment measures before 1994 as the BLS made a significant change in unemployment duration-related questions in the basic monthly CPS. Therefore, duration measures before and after 1994 are not directly comparable. ${ }^{17}$

Since monthly, and even quarterly, data can be volatile and noisy at the state level, in our main specifications we aggregate all data to the state-year level which sums to 1600 observations on 50 states from 1982 to $2013 .{ }^{18}$ For analysis related to short-term and long-term unemployment, we use 1000 state-year observations from 1994-2013. Table 1 presents summary statistics on key wage and unemployment variables. Figures 1, 2, and 3 show long-term trends in nominal wages, real wage inflation (change in log real wage), and measures of the unemployment rate, respectively. Figure 4 shows a scatter plot of the relationship between the dependent variable — change in log wage (adjusted by change in CPI)—and the unemployment rate observed in the data. The chart provides visual evidence of potential nonlinearity in the wage inflation and unemployment tradeoff. The wide variation in the unemployment rate across states over years is also apparent in the chart.

\section{Empirical Evidence on Nonlinear Phillips Curves}

We first explore nonlinearity in the Phillips curve using empirical estimates of our baseline specifications (3) and (4). Results reported in Table 2 use hourly wage measures from the CPSORG data as the other measures yielded qualitatively similar estimates and hence are not shown

\footnotetext{
${ }^{17}$ See Abraham and Shimer (2001) for a discussion.

${ }^{18}$ In constructing alternative measures of labor market utilization for states, BLS uses 4-quarter averages to improve the reliability of state-level estimates due to small sample sizes (BLS, 2015). The BLS website states:

"Due to the small state sample sizes, neither monthly nor quarterly statewide data from the CPS satisfy BLS publication standards.”
} 
for the baseline specifications. ${ }^{19}$ The estimated coefficient on the unemployment rate for a standard linear wage-price Phillips curve using equation (3) is reported in column 1. It shows that the curve is negatively sloped; the coefficient on the unemployment rate is negative and significantly different from zero. The coefficient indicates that a percentage point decline in the state unemployment rate is associated with a 0.33 percentage point increase in real wage inflation. ${ }^{20}$

Our baseline estimate of -0.33 is well within the ballpark of previously reported estimates of the slope of the wage-price Phillips curve. Ball and Moffitt (2001) used CPS data aggregated to cohort-education-year level and estimated a wage-price Phillips curve model augmented by wage aspirations to find a slope estimate of around -0.3. Our estimates are also within the range of time-series-based estimates. Gallegati et. al. (2011) used aggregate times-series data from 1948 to 2009 and estimated a slope coefficient of -0.35 . Staiger et al. (2001) obtained a slope coefficient of -0.4. Our estimates are, however, different from Gali (2011), who estimated a much smaller slope of -0.08 .

Column 2 of Table 2 relaxes the constant slope assumption of the Phillips curve and shows results for the piecewise-linear specification presented in equation (4). A linear spline specification is estimated with one knot set at the sample average unemployment rate of 6.1 percent. Estimates indicate that a percentage point decline in the unemployment rate is associated with an increase in real wage inflation of about 0.55 percentage point. The slope of the curve beyond the knot of 6.1 percent is obtained by adding the coefficient on the unemployment rate and the spline term. Along this segment, a percentage point decline in the unemployment rate is associated with a 0.28 percentage point increase in real wage inflation. The statistically

\footnotetext{
${ }^{19}$ We show robustness with respect to alternative wage measures in Table 5.

${ }^{20}$ Note that since the dependent variable is a difference in logs, the coefficients need to be multiplied by 100 to have a percentage point interpretation.
} 
significant coefficient on the linear spline term is evidence in favor of a nonlinear Phillips curve. Figure 5 shows the estimated Phillips curve with a 95 percent confidence interval using the linear spline specification from column 2 in Table 2.

Next, we enhance the linear spline specification in column 2 and estimate a restricted cubic spline model with three knots located at equally-spaced percentiles of the distribution of the unemployment rate in the sample. The three knots are set at unemployment rates of 3.7, 5.7, and 9 percent. Results in column 3 are similar to those in column 2 and a statistically significant spline term can be interpreted as evidence in favor of a nonlinear Phillips curve. Figure 6 plots the estimated Phillips curve using results in column 3 with a 95 percent confidence interval. The figure confirms that one knot sufficiently captures the nonlinearity in the Phillips curve, as the slope does not change significantly between the second and third knot.

Column 4 of Table 2 introduces convexity by adding the reciprocal of the unemployment rate to the linear baseline specification from column 1 , similar to a host of previous studies on the convex Phillips curve. The positive and significant coefficient on the reciprocal term suggests that linearity of the Phillips curve is soundly rejected. Overall, results in columns 2, 3, and 4 of Table 2 point to resounding rejection of linearity in the Phillips curve for a wide variety of functional forms. Since we get similar results using a linear spline with one knot, a restricted cubic spline with three knots, and a convex specification with the reciprocal of the unemployment rate, we focus on the linear spline specification in the remainder of the robustness checks. Our results remained statistically indistinguishable from each other when we estimated linear spline models with one knot set at a range of unemployment rates on either side of the sample average rate of 6.1 percent. Therefore, we continue to report results for the linear spline model with one knot at the sample average rate. 


\section{Robustness to alternative inflation measures}

Table 3 shows robustness checks with respect to the inflation measure used to adjust the dependent variable — change in the log of the nominal wage. Table 3 column 1 simply reproduces the results from Table 2 column 2 that used change in the log of CPI(U) to adjust wages for inflation and construct $\Delta w_{s t}-\Delta p_{s t-1}$. Table 3 column 2 uses core CPI to adjust nominal wages and shows that the estimated coefficients on the unemployment rate and the spline term are statistically and quantitatively indistinguishable from those in column 1 . Results in columns 1 and 2 are based on using lagged inflation as a proxy for expected inflation, which assumes adaptive expectations. In column 3 we use a measure of expected inflation—one year ahead inflation expectations from SPF-to adjust nominal wages and construct $\Delta w_{s t}-\mathrm{E} \Delta p_{s t-1}$ as is done in expectations-augmented versions of the Phillips curve. The estimates are remarkably similar to columns 1 and 2 and a significant spline term still indicates that linearity is strongly rejected. ${ }^{21}$

\section{Robustness to additional covariates}

Table 4 examines robustness of the results to the inclusion of additional covariates in our baseline linear spline specification in equation (4). For comparison, column 1 reproduces our baseline linear spline estimates with one knot set at the sample average unemployment rate of 6.1 percent. Column 2 includes a full set of linear state time trends to account for any omitted

\footnotetext{
${ }^{21}$ We also checked the robustness of our estimates to the possibility that the wage-price relationship is a "wage curve" (rather than the Phillips curve). We estimated a wage level equation and included a lagged wage variable on the right hand side in addition to the unemployment rate. Sure enough, we got a highly significant coefficient of 0.68 on lagged wage. Not surprisingly, this is similar to what Blanchflower and Levine (2015) find using CPS data. The estimated relationship between wages and unemployment rate was statistically and qualitatively similar in both "wage curve" and Phillips curve specifications. Also, we continue to find evidence of significant nonlinearity in the wage curve, just as we do in case of the Phillips curve.
} 
variables correlated with the unemployment rate that may have trended differentially across states over time. For example, the specification in column 2 would account for productivity growth that trended linearly but differentially across states. The results with the inclusion of state time trends are essentially the same as the results in column 1 , with the spline term still strongly significant and estimates of slope little-changed.

Column 3 shows the sensitivity of our results to the inclusion of state-level demographic variables such as average age, percent of the population that is female, percent of the population that is non-Hispanic white, black, and Hispanic, and the share of adults with different levels of educational attainment. Demographic control variables such as these capture the effect of any other confounding factors that vary across states and over time in a way that is not accounted for by a state-specific linear trend. Once again, the conclusion regarding nonlinearity of the Phillips curve remains unchanged with the coefficients largely similar to those in columns 1 and $2 .{ }^{22}$

Column 4 of Table 4 accounts for dynamic effects of the unemployment rate by exploring sensitivity to controlling for unemployment rate lags. As pointed out in Gordon (1997), inflation responds to both the level and change in the unemployment rate and, therefore, Phillips curve specifications should control for either lags in the unemployment rate or for the change in the rate. We explore sensitivity of our estimates to inclusion of regressors measuring the change in the unemployment rate and the change in the spline variable. The results are equivalent to controlling for current and lagged unemployment and current and lagged spline terms. The coefficient on the unemployment rate and the spline term can be interpreted as the two-period dynamic effect of the unemployment rate on wage inflation. Results shown in column 4 suggest that a one percentage point decrease in the unemployment rate in the current and previous year is

\footnotetext{
${ }^{22}$ We note that the statistical significance of estimates on the spline term on columns 1-3 may partly reflect large sample sizes of 1600 observations, not available using time-series data.
} 
associated with a 0.43 percentage point increase in wage inflation when the unemployment rate exceeds the long-term average rate and a significantly smaller 0.28 percentage points when the rate is higher than the long-term average rate. The spline term in column 4 , however, is significant only at the 10 percent level and insignificant at the 5 percent level. Column 5 adds an explicit productivity measure to the enhanced specification in column 4 to account for any remaining differences in state-specific productivity growth over time, over and above what is already accounted for by year-specific effects, and the results show that the estimates remain largely unchanged from column 4 as the coefficients remain significant but only at the 10 percent level. ${ }^{23}$ Overall, results presented in Table 4 suggest strong evidence of nonlinearity, which emerges in parsimonious specifications in columns 1-3, but statistically weakens after controlling for demographics and the unemployment rate dynamics in columns 4 and 5.

\section{Robustness to alternative wage measures}

Table 5 explores sensitivity of our linear spline Phillips curve specification to alternative measures of wages. Columns 2, 3, and 4 use different wage measures than the mean hourly measure from the CPS-ORG used so far. Column 2 uses the median wage from CPS-ORG; column 3 uses the average hourly earnings in manufacturing available from the CES; column 4 uses average weekly wages from the QCEW. In addition to state and year fixed effects included in the baseline specification, all columns include state time trends and also the change in the unemployment rate. Table 5 shows that the results remain stable to the use of alternative wage measures and the significant spline term indicates that linearity is rejected in all specifications,

\footnotetext{
${ }^{23}$ Following Blanchard and Katz (1996), we construct the log of cyclically adjusted productivity by using predicted values from a regression of log state GDP per hour on a linear and quadratic time trend for the entire sample period. The annual state GDP is from BEA and state level annual hours were constructed using average hours per week*52*household employment, where hours per week was obtained from the CPS.
} 
although it is significant only at the 10 percent level when using average hourly earnings in manufacturing in column 3 . The wage inflation-unemployment tradeoff is statistically similar to our baseline tradeoff estimate of 0.55 percentage points when the unemployment rate is below the long-term average rate and 0.28 percentage points when the unemployment rate exceeds the long-term average rate.

\section{Robustness to data frequency}

Although our preferred approach of averaging high frequency monthly and quarterly data (versus using lower frequency annual data) helps mitigate well-documented concerns regarding the reliability of sub-national labor market data due to smaller sample sizes at the state level, it may lead to aggregation bias. Therefore, we also check the robustness of our results to using monthly and quarterly data. Table 6 presents results from estimating wage-price Phillips curve specifications using quarterly data (Panel A) and monthly data (Panel B). To maintain comparability with estimates using annual data, the dependent variable in Panel A is the 4quarter log change in real wage and, in Panel B, the 12-month log change in real wage. Comparing reported estimates in Table 5 with those in Panels A and Panel B of Table 6, suggests that the coefficients on the unemployment rate and the linear spline are statistically indistinguishable from each other.

\section{State-specific Phillips Curve Estimates}

Thus far, we have assumed that data can be pooled across states and reported results restricting the estimates on Phillips curve specifications to be the same across states. Does poolability across state-level panels hold? To test the hypothesis that data can be pooled across 
states, Tables 6 also reports the p-values on F-tests of poolability of state-level data at the quarterly and monthly frequency, respectively. Following Baltagi (2008), the appropriate test is a Chow-type test with a heteroskedasticity-robust variance-covariance matrix used to calculate the F-statistic on poolability. Tests on poolability reported in Table 6 are sensitive to the wage measure used and suggest that the data can be pooled across states if CPS-ORG measures of hourly wages are used. On the other hand, there is evidence of significant heterogeneity across states if hourly manufacturing wages from the CES or weekly wages from QCEW are used.

Given that the poolability tests are inconclusive, we allow all coefficients to vary by state and estimate state-specific Phillips curve specifications while accounting for cross-equation correlation in error terms across states using Seemingly Unrelated Regression (SUR) models. In doing so we allow the knot $(\bar{u})$, for the linear spline, to also be state specific and set it at the state-specific long-run average unemployment rate for each state. The standard Breusch-Pagan test soundly rejected the independence of cross-equation error terms in all specifications. Using quarterly data, Figures 7 and 8 present estimated coefficients on the unemployment rate (upper panel) and the spline term (lower panel) with associated confidence intervals and reflect some heterogeneity as well as nonlinearity in state-specific slopes of the Phillips curve. We plot statespecific results for the mean hourly wages (Figure 7) and the median hourly wages (Figure 8) from the CPS-ORG.

The point estimates plotted in the two figures suggest that most states have downward sloping and convex Phillips Curves as the coefficient on the unemployment rate is negative and the coefficient on the spline term is positive. The dashed lines on the figures show the employment-weighted average of state-specific estimates and confirm the existence of convexity at the national level that we found using pooled data. Although state-specific Phillips curve 
estimates using median hourly wages are somewhat more precise than those using the mean wages, it is hard to detect any particular pattern.

State-specific estimates using average weekly wages from the QCEW, presented in Table 7, are substantially more precise. Table 7 shows that Phillips curves for almost all states have a negative and significant slope suggesting that decline in the unemployment rate when the rate is below the long-run average is associated with accelerating real average weekly wage growth. On the other hand, there is great heterogeneity in state-specific estimates of the wage-price Phillips curve relationship when the unemployment rate is below its long-run average, as indicated by the sign on the spline term. For many states, the positive sign on the spline term is indicative of convexity, as the curve's slope-the coefficient on the unemployment rate plus the coefficient on spline-is less negative when the unemployment rate exceeds its long-run average. For some states, however, the Phillips curve relationship is concave. Overall, Table 7 points to a wide variety of Phillips curve slopes and shapes across the states. While state-specific Phillips curves are of great theoretical interest, they are relatively less consequential in the context of the onesize-fits-all monetary policy prevailing in the United States. We continue to focus on pooled estimates of the Phillips curve in the remainder of the paper.

\section{Phillips Curve Forecast Evaluation}

While finding significant nonlinearity in the U.S. Phillips curve, we have implicitly assumed that such a curve actually exists, is stable, and can be reliably used to forecast real wage growth. We acknowledge the assumption of the curve's existence as an important caveat to our results and focus on its predictive ability. Previous research has found mixed evidence on the curve’s stability and its usefulness in forecasting inflation. Does this shortcoming also extend to the 
wage-price Phillips curve that we estimate? To test the predictive ability of the Phillips curve and its stability we adopt a panel data version of a pseudo-out-of-sample-forecasting framework proposed in Stock and Watson (2008) and estimate the following autoregressive distributive lag (ADL) specification with two-way error components to obtain h-period ahead direct forecast of 4-quarter real wage growth $\Delta w_{s t}^{R}$ :

$$
\Delta w_{s t+h}^{R}=\alpha+\beta_{1}(L) u_{s t}+\beta_{2}(L) \max \left(0, u_{s t}-\bar{u}\right)+\gamma(L) \Delta w_{s t}^{R}+\kappa_{s}+\mu_{\mathrm{t}+\mathrm{h}}+\epsilon_{s t+h}
$$

In equation (6), $\Delta \mathrm{w}_{\mathrm{st}+\mathrm{h}}^{\mathrm{R}}$ is the h-period ahead 4-quarter real wage growth and, $\beta_{1}(\mathrm{~L}), \beta_{2}(\mathrm{~L})$, and $\gamma(\mathrm{L})$ are lag polynomials. ${ }^{24}$ Predicted values from (6), $\widehat{\Delta \mathrm{w}}_{\mathrm{st}+\mathrm{h} \mid \mathrm{t}}^{\mathrm{R}}$, are direct forecasts of $\Delta \mathrm{w}_{\mathrm{st}+\mathrm{h}}^{\mathrm{R}}$ given information until period t. We evaluate model-based real wage growth forecasts based on Root Mean Squared Forecast Error (RMSE). We also calculate the RMSE from a naïve h-period ahead forecast of real wage growth that is based on a random walk model for $\Delta \mathrm{w}_{\mathrm{st}}^{\mathrm{R}}$. The naïve forecast of $\Delta \mathrm{w}_{\mathrm{st}+\mathrm{h} \mid \mathrm{t}}^{\mathrm{R}}$ simply equals $\Delta \mathrm{w}_{\mathrm{st}}^{\mathrm{R}}$. A model's RMSE relative to the naïve RMSE forms the basis of forecast comparisons across different models. Directs forecasts based on specification (6) using state-level panel data presents well-known challenges as period $\mathrm{t}+\mathrm{h}$ time effects, $\mu_{\mathrm{t}+\mathrm{h}}$, need to be forecasted. Following the previous literature (Ince, 2014) we set the forecast of $\mu_{\mathrm{t}+\mathrm{h}}$ to equal the recursive mean of the estimated time effects until period t, i.e. $\hat{\mu}_{t+h}=\overline{\hat{\mu}}_{t}$.

In Table 8 we present an evaluation of 4-quarters ahead forecast of 4-quarter real wage growth $(\mathrm{h}=4)$. The left-most panel shows forecast evaluation of real wage growth using mean

\footnotetext{
${ }^{24}$ Pseudo-out-of-sample-forecasting exercise uses state-level panel data for 116 quarters from 1984:Q1 to 2012:Q4 and proceeds as follows, for example, if $h=4$. We start by estimating our model using an initial training sample from 1984:Q1 to 1993:Q4 and using the model to obtain a direct forecast of real wage growth 4-quarters ahead of 1993:Q4, i.e. for 1994:Q4. Next, we expand the training sample by one quarter and estimate the model on data from 1984:Q1 to 1994:Q1 and obtain a direct forecast of real wage growth 4-quarters ahead of 1994:Q1, i.e. for 1995:Q1. Proceeding recursively, each time expanding our estimation sample by one quarter and forecasting 4-quarters ahead and calculating the amount by which our 4-quarter ahead forecast misses actual wage growth for that period, yields out-of-sample forecast error for each of the 76 quarter from 1994:Q4 to 2012:Q4 and allows us to calculate Root Mean Squared Forecast Error (RMSE) for a particular model.
} 
wage measure from the CPS-ORG. The specification estimated in Column (1) excludes the unemployment-related variables from equation (6) and regresses $\Delta \mathrm{w}_{\mathrm{st}+\mathrm{h}}^{\mathrm{R}}$ on the lags of $\Delta \mathrm{w}_{\mathrm{st}}^{\mathrm{R}}$, state fixed effects and time effects. Column (1) of Table 8 shows that the RMSE from this model is 4.01. In comparison, at 6.34, the naïve RMSE is substantially larger. Dividing the model's RMSE with the naïve-RMSE, the model in column (1) yields a relative RMSE of 0.63. Because the relative RMSE is significantly less than 1, the model in column (1) provides a superior forecast relative to the benchmark naïve RMSE.

Comparing relative RMSEs across columns (1) and (2) suggests that adding lags unemployment rate variables and estimating a Phillips curve specification marginally improves the forecast of real wage growth as the relative RMSE in column (2) is slightly smaller than column (1). The improvement in relative RMSE, however, is rather trivial and, therefore, we can conclude the wage-price Phillips curve does not yield significantly better real wage growth forecasts than a simple autoregressive model of real wage growth. Adding the unemployment spline term in column (3) of Table 8 also leaves the relative RMSE largely unchanged. Moreover, a similar finding emerges when alternative measures of wages are used in the middle and right panels of Table 8 . Overall, Table 8 suggests that neither the Phillips curve nor a nonlinear Phillips curve specification significantly improves the 4-quarter ahead 4-quarter real wage growth forecasts.

This results needs to be placed in the context of the previous literature's findings on the Phillips curve's inability to improve upon naive price inflation forecasts at the national level. In Atkeson and Ohanian (2001), for example, relative RMSEs from Phillips curve specifications exceeded one, suggesting that the Phillips curve forecasts were inferior to a naïve forecast of price inflation. We came to the same conclusion when we used national level time-series data. 
Our findings on real wage growth forecasts using state-level panel data are different. Although both the linear and nonlinear Phillips curves do not improve upon forecasts from a simple autoregressive model, they do not cause deterioration in the forecast either. Moreover, they do substantially better than the naïve model.

\section{Impact of Short-Term vs. Long Term Unemployment on Real Wage Inflation}

Table 9 presents results for the Phillips curve specification in equation (5) with the unemployment rate decomposed into short-term and long-term unemployment rates (Smith, 2014; Kiley, 2014). Like much of the previous literature examining the relationship of various forms of labor market slack with wages, we use percent annual growth in real wage as the dependent variable. The short-term unemployment rate is defined as the share of unemployed workers with unemployment spells of 6 months or less. The short-term unemployment rate over 1994-2013 averages 4.5 percent of the labor force with a standard deviation of 0.95 ; the long term unemployment rate averages 1.5 percent of the labor force with a standard deviation of 1.3 percent. As noted earlier, we restrict analysis to the period 1994- 2013, as unemployment duration-related questions in the CPS were revised in 1994, potentially affecting comparability of pre-1994 and post-1994 measures of long-term unemployment. In subsequent analysis, we report results using annual data as those using higher-frequency quarterly (monthly) data with real wage growth calculated using 4-quarter (12-month) changes were very similar and are available upon request.

Results in Table 9 suggest that short-term unemployment has a strong relationship with wage inflation, but long-term unemployment does not exert significant pressure on wage inflation in regressions where the measure of wage inflation is the average real wage (columns 1, 
3, and 4). ${ }^{25}$ Our results using average wages are consistent with the findings in Krueger et al. (2014) who estimate a real wage Phillips curve using annual national data from 1976-2013 and find that, in contrast to the short-term unemployment rate, long-term unemployment has a weak and insignificant relationship with average real wage growth. Our results also are in line with Linder et al. (2014), who find that hourly compensation forecasts based on a short-term unemployment gap measure outperformed those based on a total unemployment gap measure that uses both short-term and long-term unemployment. Our findings are, however, different from Aaronson and Jordan (2014), who also use state-level data and find that long-term unemployment is significantly correlated with real wage growth in specifications that include both short-term and long-term unemployment measures.

Long-term unemployment becomes statistically significant in our results only when we use growth in the real median wage. This result is consistent with findings in Smith (2014) who also uses median wages. A potential explanation is recent variation in average wage growth may be largely concentrated among skilled workers who form a small component of the long-term unemployed. In contrast, median wage growth is likely more sensitive to wage growth among low-skilled workers than is average wage growth. Since low-skilled workers form a large component of the long-term unemployed, it makes sense that long-term unemployment should exert more pressure on median wage growth than on mean wage growth.

Table 10 explores sensitivity of the differential effects of short-term versus long-term unemployment we observe when we use average wage from the CPS-ORG. Results using

\footnotetext{
${ }^{25}$ We acknowledge that there may not be enough independent variation in long- and short-term unemployment to identify their coefficients separately, as they tend to move together. The significance of short-term unemployment suggests that our results are not driven by collinearity, as it almost always leads to variance inflation and lack of statistical significance. However, it can lead to variance deflation in exceptional cases (Mela and Kopalle, 2002).
} 
average hourly earnings and average weekly wages were similar and are not reported. Column 1 reproduces the baseline estimates with state and time fixed effects. Column 2 adds state time trends and column 3 further enhances the estimated specification by including demographics as described above (including average age, percent female, percent white, black, and Hispanic, and shares with different levels of educational attainment). Results remain mostly similar across the three columns with long-term unemployment not significantly associated with average real wage inflation.

\section{Conclusion}

Previous research on a nonlinear Phillips curve for the U.S. case used mainly time-series data at the national level and found mixed evidence with some recent studies either rejecting nonlinearity or estimating only modest convexity. Most papers also have not made a distinction between the relative impacts of short-term vs. long-term unemployment on wages. Using statelevel data from1982 to 2013 we find strong evidence that the wage-price Phillips curve is nonlinear and convex; declines in the unemployment rate below the historical average unemployment rate exert significantly higher wage pressures than changes in the unemployment rate above the historical average. Our choice of a specific knot—-the sample average unemployment rate-for the piecewise-linear specification of the Phillips curve that we estimate, may be somewhat arbitrary. We therefore test nonlinearity in the Phillips curve for a range of unemployment rates on either side of the long-term average rate and come to the same conclusion - the Phillips curve using state-level data is strongly nonlinear and convex. We also find that short-term unemployment has a strong relationship with both average and median wage growth, while long-term unemployment appears to only influence the growth in median wages. 


\section{References}

Aaronson, D., Jordan, A., 2014. Understanding the Relationship between Real Wage Growth and Labor Market Conditions. Chicago Fed Letter.

Abraham, K.G., Shimer, R., 2001. Changes in unemployment duration and labor force attachment. National Bureau of Economic Research.

Akerlof, G.A., Dickens, W.T., Perry, G.L., Gordon, R.J., Mankiw, N.G., 1996. The macroeconomics of low inflation. Brookings papers on economic activity 1-76.

Ball, L., Mankiw, N.G., 1994. Asymmetric price adjustment and economic fluctuations. National Bureau of Economic Research.

Ball, L., Moffitt, R., 2001. Productivity growth and the Phillips curve. National Bureau of Economic Research.

Ball, L.M., Mazumder, S., 2011. Inflation dynamics and the great recession. National Bureau of Economic Research.

Baltagi, B. (2008). Econometric analysis of panel data (Vol. 1). John Wiley \& Sons.

Barnes, M.L., Olivei, G.P., 2003. Inside and outside bounds: Threshold estimates of the Phillips curve. New England Economic Review 3-18.

Blanchard, O., Katz, L.F., 1996. What we know and do not know about the natural rate of unemployment. National Bureau of Economic Research.

Blanchard, O.J., Katz, L., 1999. Wage dynamics: reconciling theory and evidence. National bureau of economic research.

Blanchflower, D.G., Oswald, A.J., 1994. The wage curve. MIT press.

Blanchflower, D.G., Oswald, A.J., 2005. The wage curve reloaded. National Bureau of Economic Research.

Blanchflower, D. G., \& Levin, A. T. (2015). Labor Market Slack and Monetary Policy. National Bureau of Economic Research. Retrieved from http://www.nber.org/papers/w21094

Bratsberg, B., Turunen, J., 1996. Wage curve evidence from panel data. Economics Letters 51, 345-353.

Bureau of Labor Statistics. (2015). Alternative Measures of Labor Underutilization for States. Retrieved May 1, 2015, from http://www.bls.gov/lau/stalt.htm.

Card, D., 1995. The wage curve: a review. JSTOR.

Carlino, G., DeFina, R., 1998. The differential regional effects of monetary policy. Review of Economics and Statistics 80, 572-587.

Carlino, G., DeFina, R., 1999. The differential regional effects of monetary policy: Evidence from the US states. Journal of Regional Science 39, 339-358.

CEPR, n.d. Center for Economic and Policy Research. 2014. CPS ORG Uniform Extracts, Version 1.9 . Washington, DC.

Clark, P., Laxton, D., Rose, D., 1996. Asymmetry in the US output-inflation nexus. Staff PapersInternational Monetary Fund 216-251.

Clark, P.B., Laxton, D., 1997. Phillips Curves, Phillips Lines and the Unemplyment Costs of Overheating. International Monetary Fund.

Coen, R.M., Eisner, R., Marlin, J.T., Shah, S.N., 1999. The NAIRU and wages in local labor markets. American Economic Review 52-57.

Debelle, G., Laxton, D., 1997. Is the Phillips curve really a curve? Some evidence for Canada, the United Kingdom, and the United States. Staff Papers-International Monetary Fund 249-282. 
Dupasquier, C., Ricketts, N., 1998. Non-linearities in the output-inflation relationship. Price Stability, Inflation Targets, and Monetary Policy 131-73.

Dupont, W.D., Dupont, W.D., 2009. Statistical modeling for biomedical researchers: a simple introduction to the analysis of complex data. Cambridge University Press.

Eliasson, A.-C., 2001. Is the short-run Phillips curve nonlinear? Empirical evidence for Australia, Sweden and the United States. Sveriges Riksbank Working Paper Series.

Filardo, A.J., 1998. New evidence on the output cost of fighting inflation. Economic ReviewFederal Reserve Bank of Kansas City 83, 33-62.

Fitzgerald, T., Nicolini, J.P., 2013. Is There a Stable Relationship Between Unemployment and Future Inflation? Evidence from US Cities. Working Paper. Federal Reserve Bank of Minneapolis. Forthcoming.

Fuhrer, J.C., Olivei, G.P., Tootell, G., 2012. Inflation dynamics when inflation is near zero. Journal of Money, Credit and Banking 44, 83-122.

Galí, J. (2011). The return of the wage Phillips curve. Journal of the European Economic Association, 9(3), 436-461.

Gallegati, M., Gallegati, M., Ramsey, J. B., \& Semmler, W. (2011). The US Wage Phillips Curve across Frequencies and over Time*. Oxford Bulletin of Economics and Statistics, 73(4), 489-508.

Gordon, R.J., 1997. The Time-Varying NAIRU and its Implications for Economic Policy. Journal of Economic Perspectives 11, 11-32. doi:10.1257/jep.11.1.11

Huh, H., Lee, H.H., Lee, N., 2009. Nonlinear Phillips curve, NAIRU and monetary policy rules. Empirical Economics 37, 131-151.

Ince, O. (2014). Forecasting exchange rates out-of-sample with panel methods and real-time data. Journal of International Money and Finance, 43, 1-18. Kiley, M.T., 2014. An Evaluation of the Inflationary Pressure Associated with Short-and Long-term Unemployment.

Krueger, A.B., Cramer, J., Cho, D., 2014. Are the long-term unemployed on the margins of the labor market? Economic Studies at Brookings.

Laxton, D., Meredith, G., Rose, D., 1995. Asymmetric effects of economic activity on inflation: Evidence and policy implications. Staff Papers-International Monetary Fund 344-374.

Laxton, D., Rose, D., Tambakis, D., 1999. The US Phillips curve: The case for asymmetry. Journal of Economic Dynamics and Control 23, 1459-1485.

Linder, H., Peach, R., Rich, R., 2014. The Long and Short of It: The Impact of Unemployment Duration on Compensation Growth. Liberty Street Economics.

Llaudes, R., 2005. The Phillips curve and long-term unemployment. European Central Bank.

Martínez-García, E., Wynne, M., 2014. An international examination of the global slack hypothesis.

Nijkamp, P., Poot, J., 2005. The last word on the wage curve? Journal of Economic Surveys 19, 421-450.

Atkeson, A., \& Ohanian, L. E. (2001). Are Phillips curves useful for forecasting inflation? Federal Reserve Bank of Minneapolis Quarterly Review, 25(1), 2-11.

Schaling, E., 2004. The nonlinear Phillips curve and inflation forecast targeting: Symmetric versus asymmetric monetary policy rules. Journal of Money, Credit, and Banking 36, 361-386. 
Schmitt, J., 2003. Creating a consistent hourly wage series from the Current Population Survey's Outgoing Rotation Group, 1979-2002. Center for Economic and Policy Research, Washington, DC.

Shapiro, C., Stiglitz, J.E., 1984. Equilibrium unemployment as a worker discipline device. The American Economic Review 433-444.

Smith, C.L., 2014. The Effect of Labor Slack on Wages: Evidence from State-Level Relationships. FEDS Notes Board of Governors of the Federal Reserve System (U.S.) 2014-06-02.

Staiger, D., Stock, J. H., \& Watson, M. W. (2001). Prices, Wages and the US NAIRU in the 1990s. National Bureau of Economic Research. Retrieved from http://www.nber.org/papers/w8320

Stock, J. H., \& Watson, M. W. (2008). Phillips curve inflation forecasts. National Bureau of Economic Research. Retrieved from http://www.nber.org/papers/w14322.

Stiglitz, J., 1997. Reflections on the natural rate hypothesis. The Journal of Economic Perspectives $3-10$.

Tambakis, D.N., 1999. Monetary policy with a nonlinear Phillips curve and asymmetric loss. Studies in Nonlinear Dynamics \& Econometrics 3.

Tambakis, D.N., 2009. Optimal monetary policy with a convex Phillips curve. The BE Journal of Macroeconomics 9.

Turner, D., 1995. Speed limit and asymmetric inflation effects from the output gap in the major seven economies. OECD Economic Studies 24, 57-87.

Whelan, K., 1997. Wage curve vs. Phillips curve: are there macroeconomic implications? Board of Governors of the Federal Reserve System Finance and Econ. Disc. Series 97-51. 
Figure 1: Average Hourly Wage (Nominal)

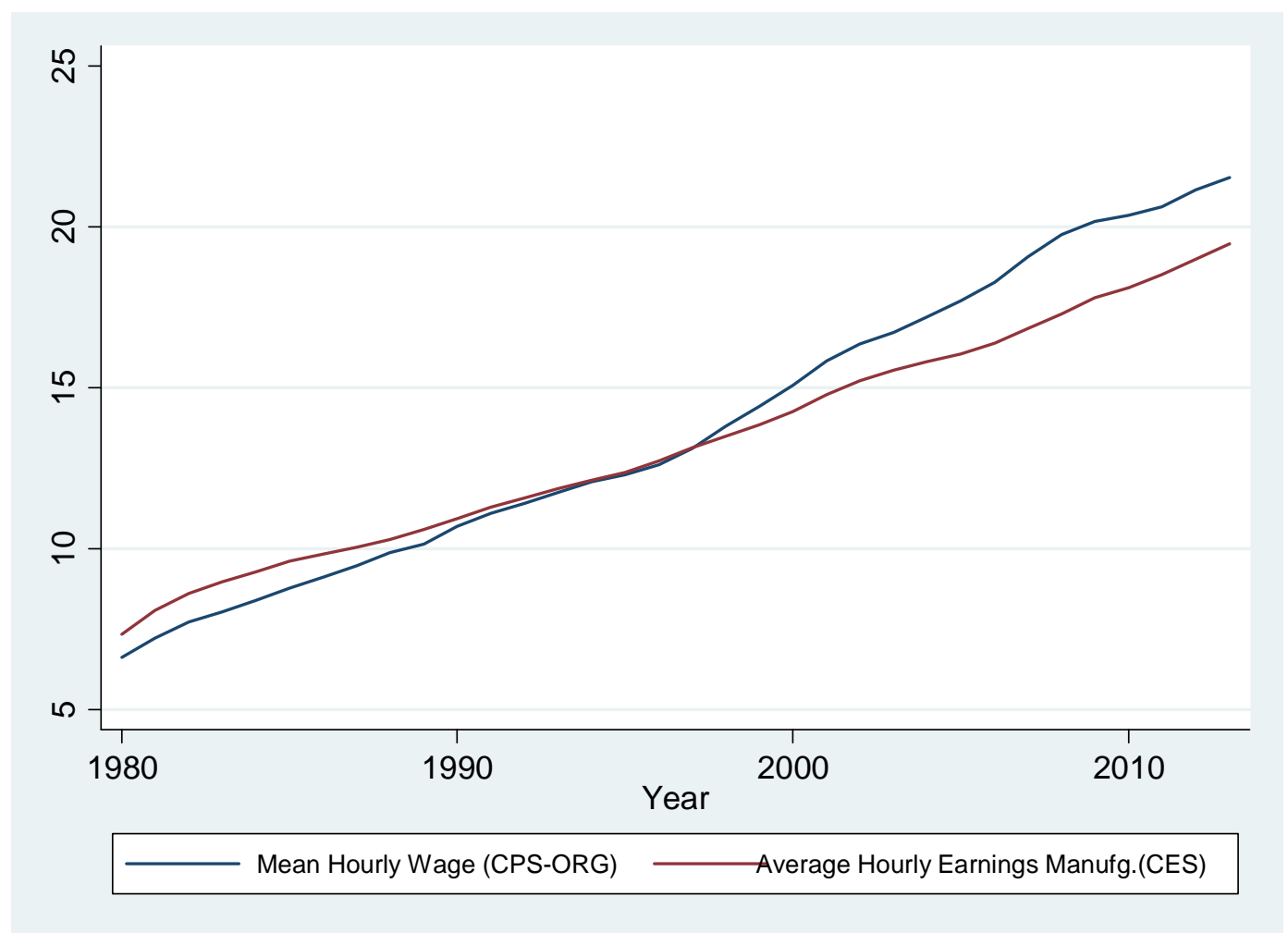

Source: Authors' calculations from Bureau of Labor Statistics, Current Population Survey (CPS-ORG) and Bureau of Labor Statistics, Current Employment Statistics (CES) 
Figure 2: Annual Change in Log Real Hourly Wage

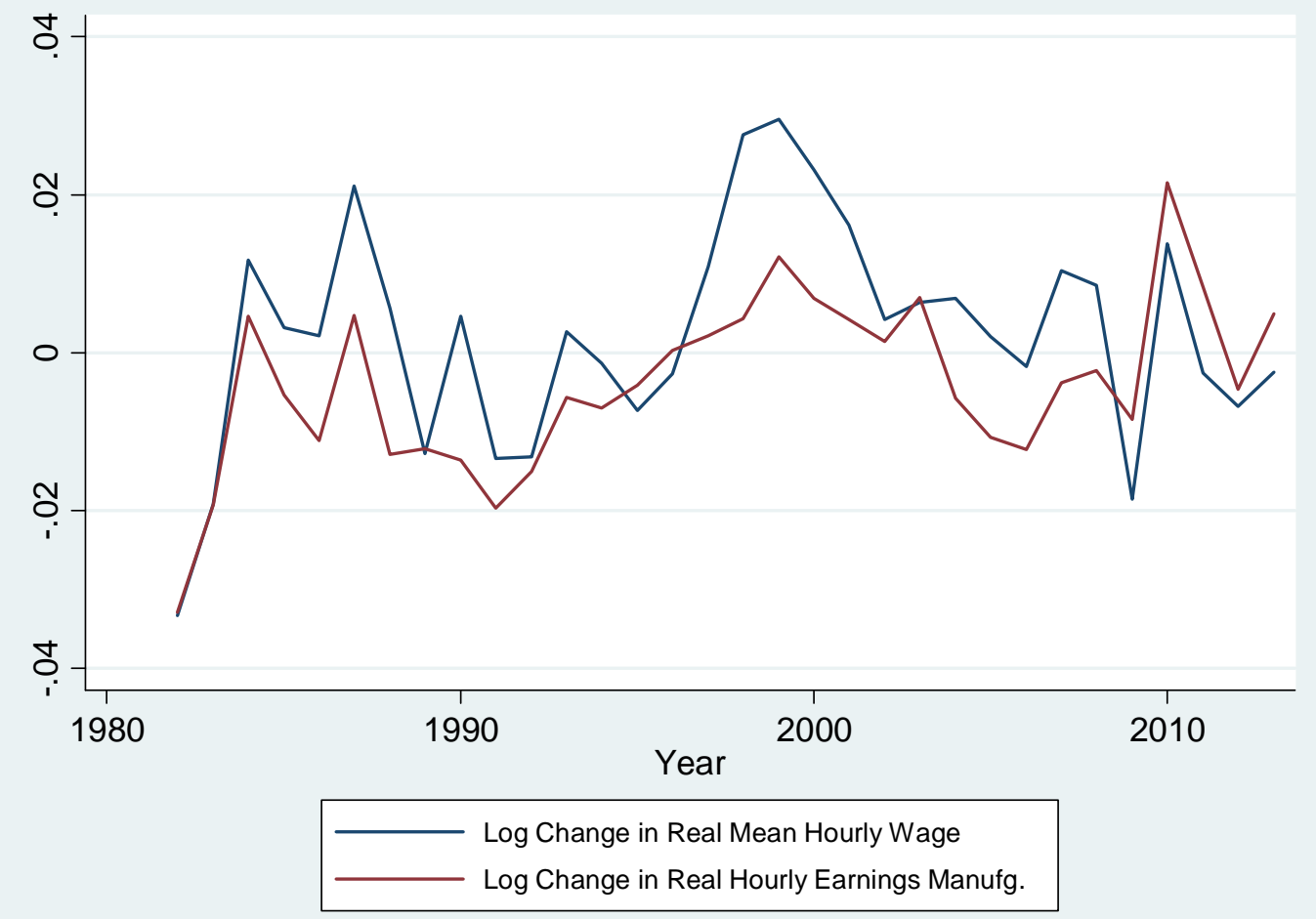

Source: Authors' calculations from Bureau of Labor Statistics, Current Population Survey (CPS-ORG) and Bureau of Labor Statistics, Current Employment Statistics (CES) 
Figure 3: Trend in Unemployment Rate

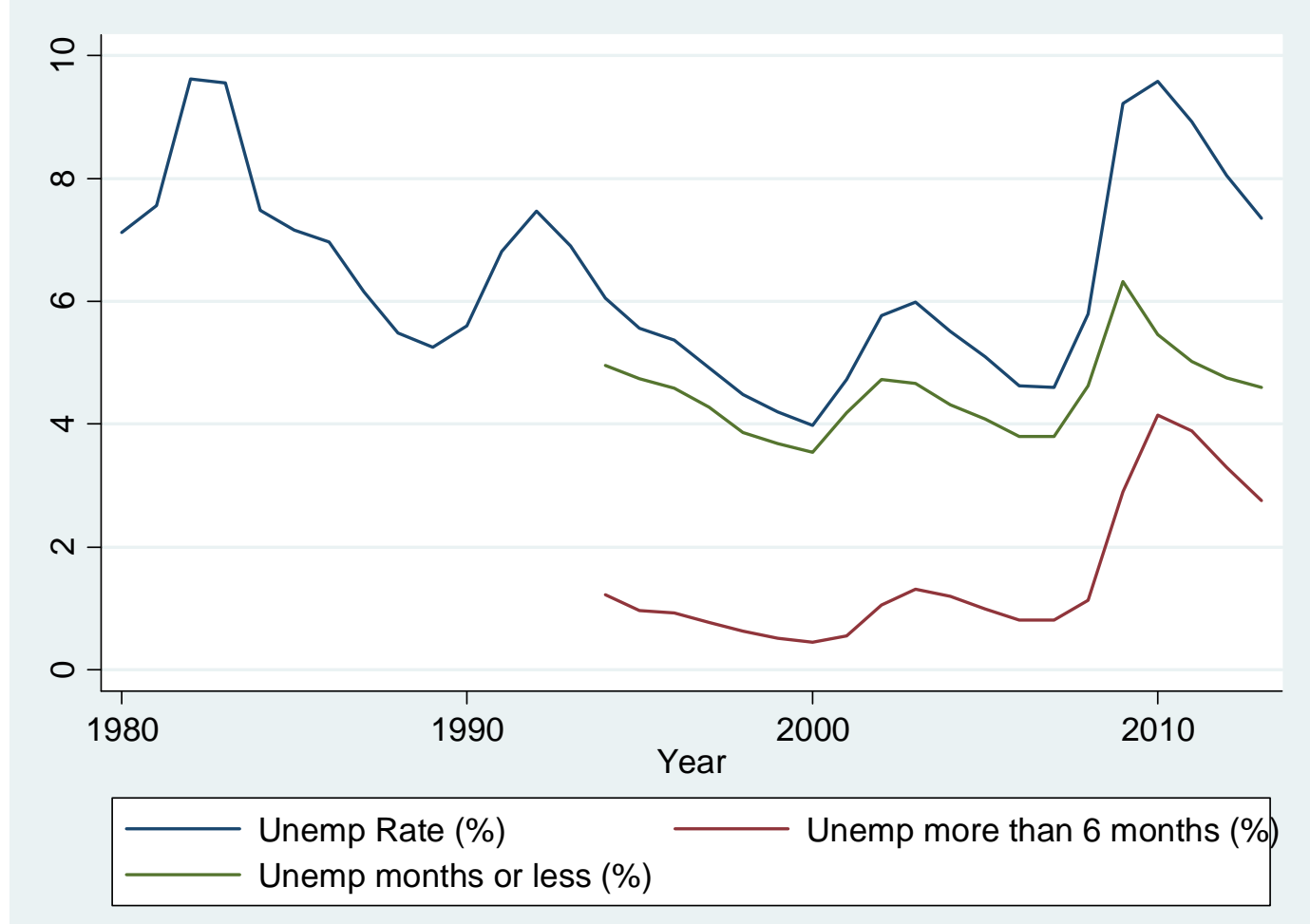

Source: Authors’ calculations from Bureau of Labor Statistics, Current Population Survey (CPS) 
Figure 4: Scatter Plot of Real Wage Inflation (Log Change) and Unemployment Rate

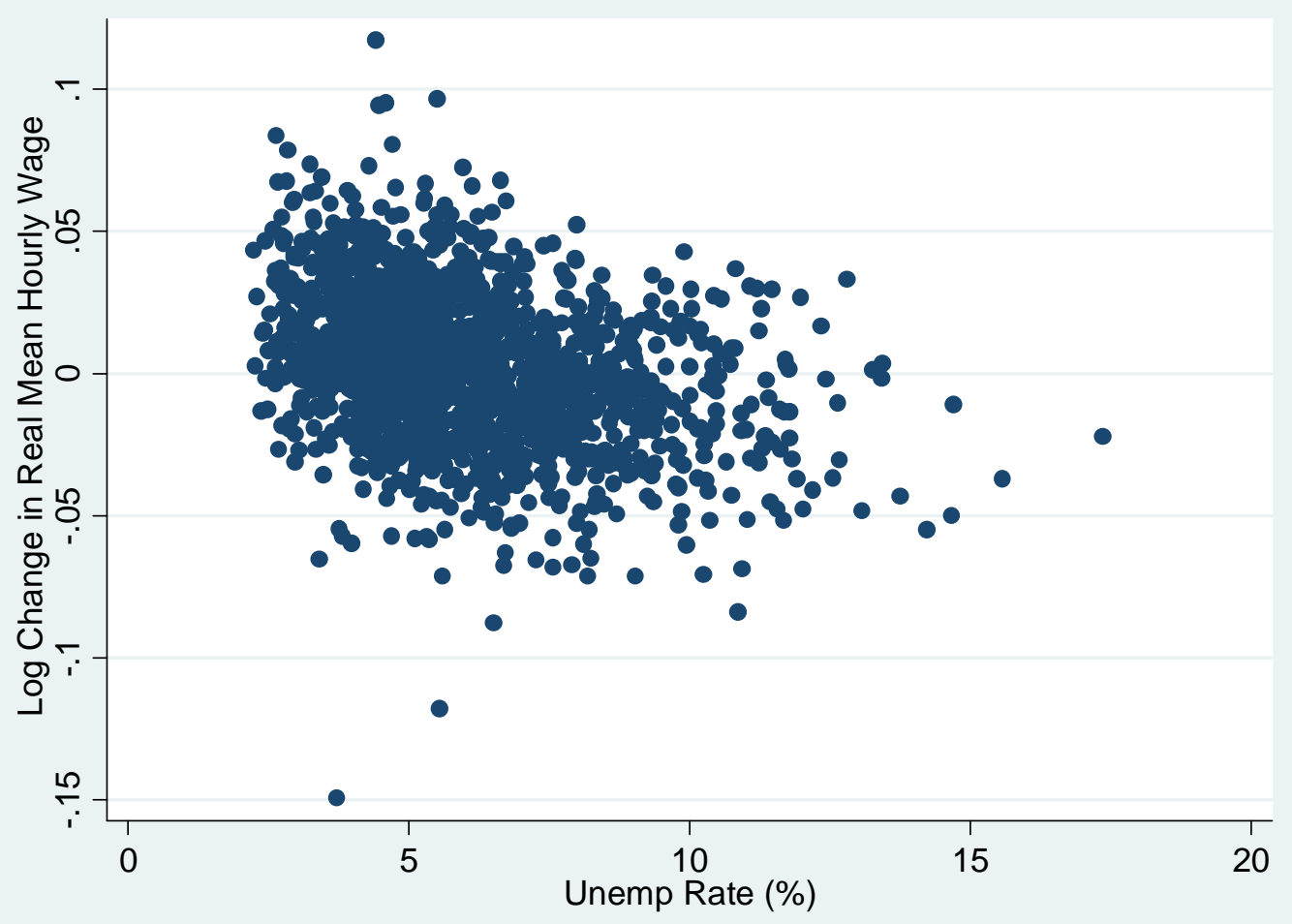

Source: Authors' calculations from Bureau of Labor Statistics, Current Population Survey (CPS) and Current Population Survey, Outgoing Rotation Group (CPS-ORG) 
Figure 5: Estimated Phillips Curve with Linear Spline Specification

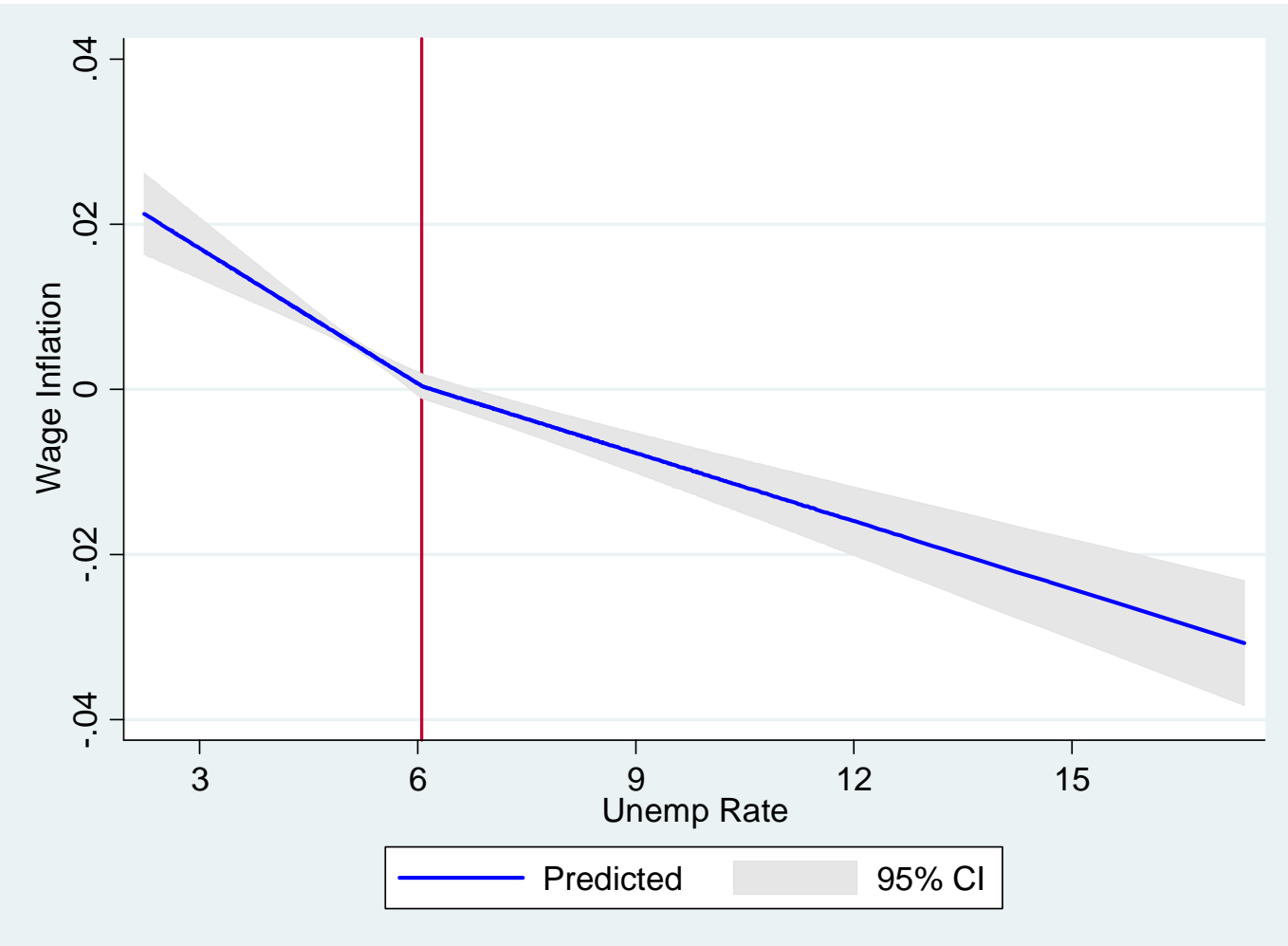

Note: Line on the X-axis shows the knot for linear spline at 6.1\%.

Source: Authors' analysis from Bureau of Labor Statistics, Current Population Survey (CPS) and Current Population Survey, Outgoing Rotation Group (CPS-ORG) 
Figure 6: Estimated Phillips Curve with Restricted Cubic Spline

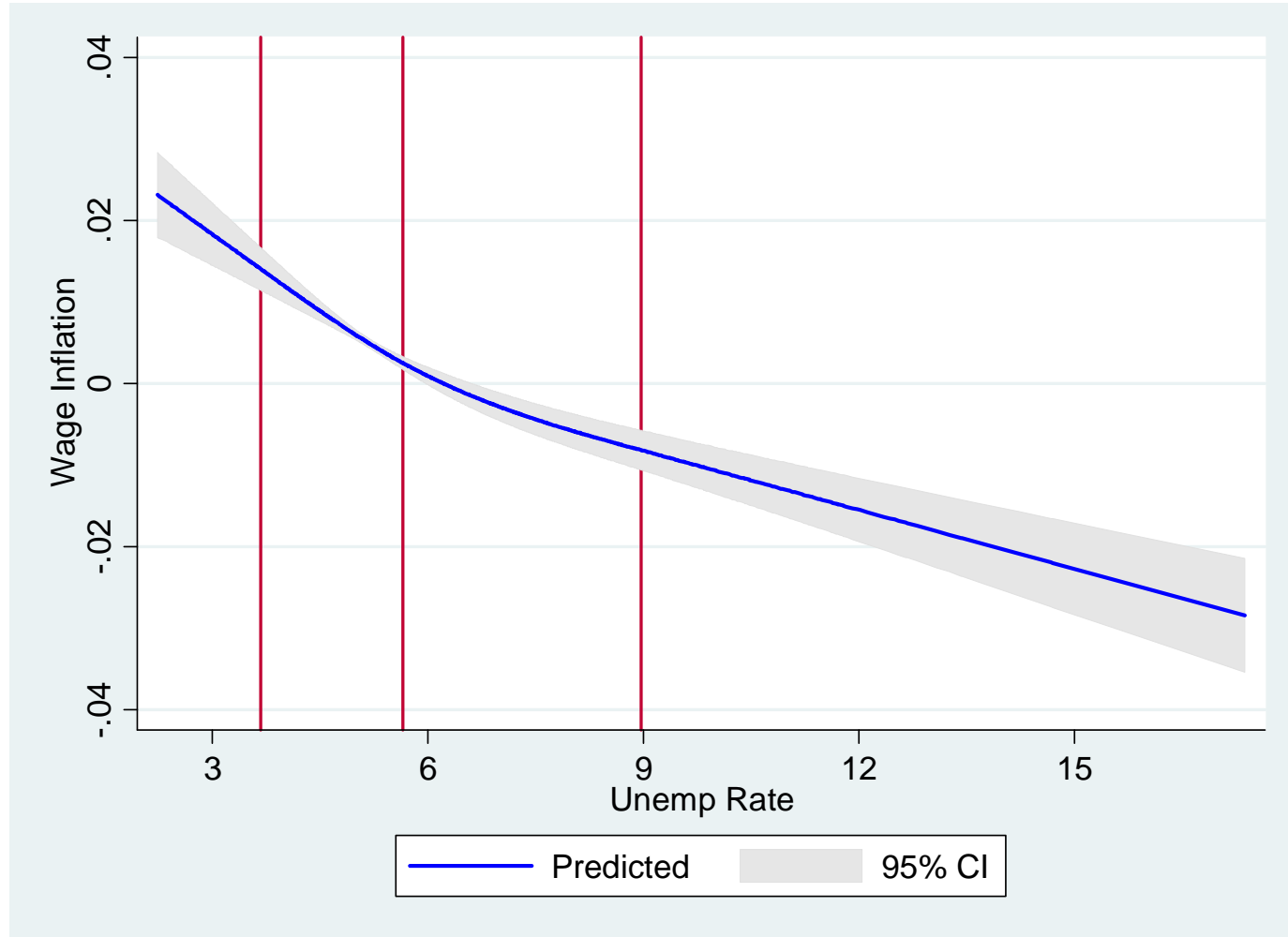

Note: Lines on the X-axis show the knots for restricted cubic spline.

Source: Authors' analysis from Bureau of Labor Statistics, Current Population Survey (CPS) and Current Population Survey, Outgoing Rotation Group (CPS-ORG) 
Figure 7: State-Specific Seemingly Unrelated Regression Estimates of Wage-Price Phillips Curve (Wage Measure: : 4-quarter Change in Log Real Mean Wage from the CPS-ORG)
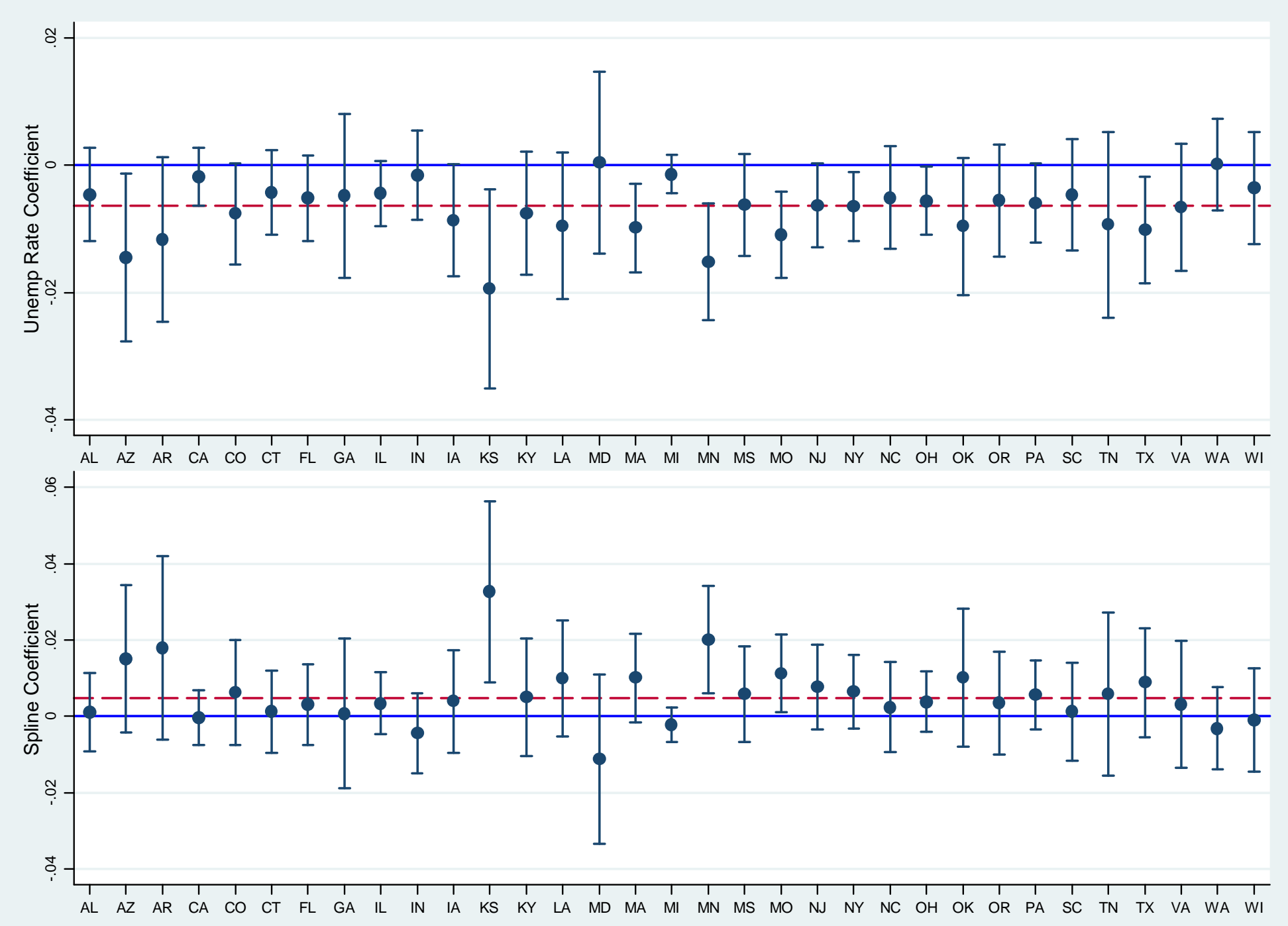

95 percent Confidence Intervals presented around point estimates. The red dashed lines are weighted average across states. 
Figure 8: State-Specific Seemingly Unrelated Regression Estimates of Wage-Price Phillips Curve (Dependent Variable: 4-quarter Change in Log Real Median Wage from the CPS-ORG)

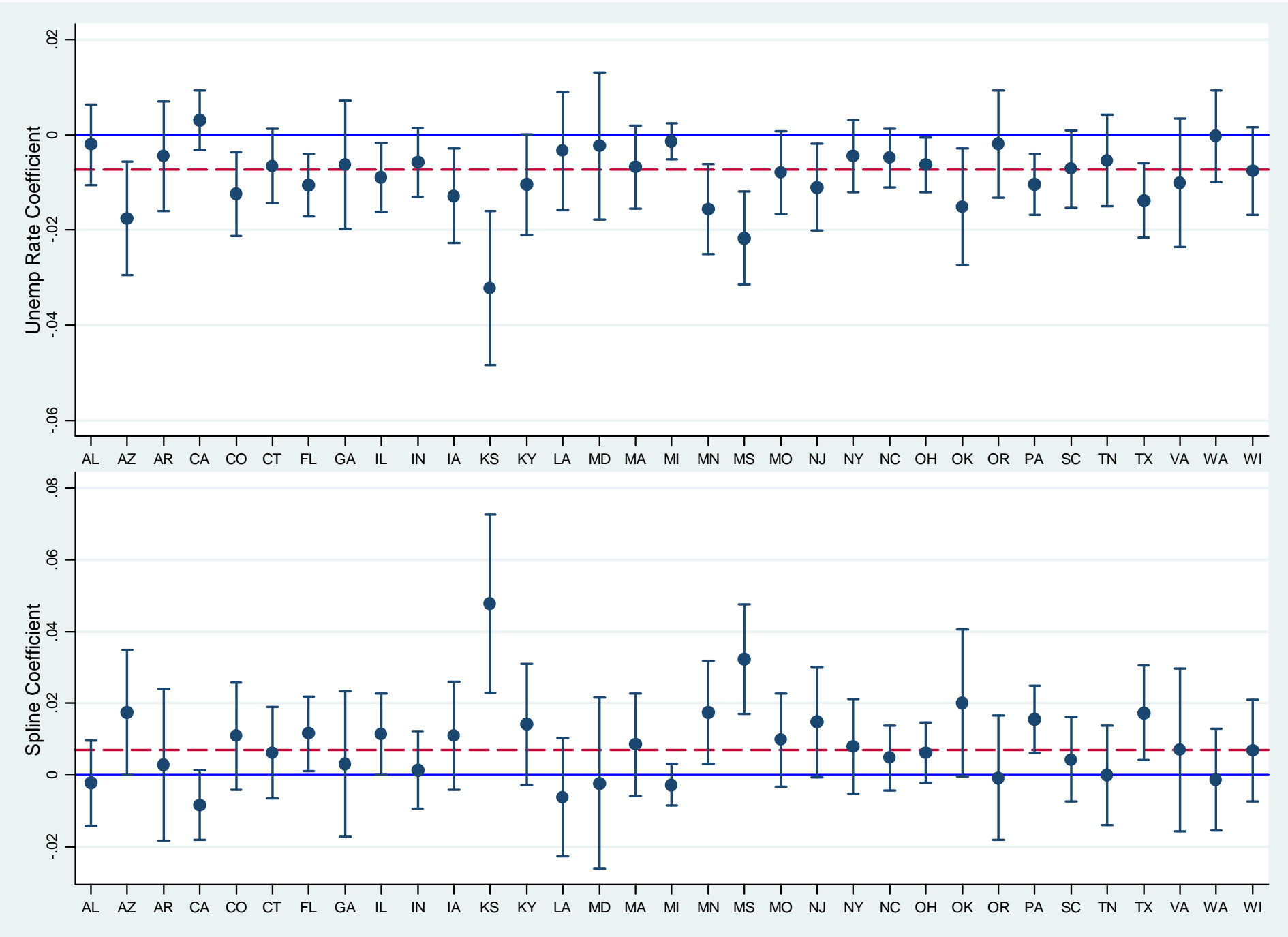

95 percent Confidence Intervals presented around point estimates. The red dashed lines weighted average across states. 
Table 1: Summary Statistics

\begin{tabular}{|c|c|c|c|}
\hline & (1) & (2) & (3) \\
\hline & Mean & Std. Dev & Median \\
\hline Mean Hourly Wage (CPS-ORG) & 17.03 & 3.49 & 17.02 \\
\hline Median Hourly Wage (CPS-ORG) & 13.51 & 2.53 & 13.61 \\
\hline Average Hourly Earnings Manufg.(CES) & 15.72 & 2.81 & 15.36 \\
\hline Average Weekly Wages (QCEW) & 749.06 & 175.12 & 740.25 \\
\hline CPI-U & 189.62 & 27.26 & 188.32 \\
\hline Core-CPI & 195.41 & 24.59 & 193.85 \\
\hline Real Mean Hourly Wage (\% change) & 0.68 & 2.32 & 0.57 \\
\hline Real Median Hourly Wage (\% change) & 0.31 & 2.40 & 0.39 \\
\hline Real Hourly Earnings Manufg. (\% change) & 0.18 & 2.98 & -0.08 \\
\hline Real Avg. Weekly Wage (\% change) & 0.73 & 1.65 & 0.70 \\
\hline Unemp Rate (\%) & 6.01 & 2.04 & 5.45 \\
\hline Unemp >6 months (\%) & 1.54 & 1.29 & 1.05 \\
\hline Unemp $<=6$ months (\%) & 4.50 & 0.95 & 4.42 \\
\hline
\end{tabular}


Table 2: Estimates of Wage-Price Phillips Curve Using State-Level Data (Dependent Variable: Change in Log Wage minus Lagged Change in Log CPI-U)

\begin{tabular}{|c|c|c|c|c|}
\hline & $\begin{array}{c}(1) \\
\text { Linear }\end{array}$ & $\begin{array}{c}(2) \\
\text { Linear Spline } \\
(1 \text { Knot })\end{array}$ & $\begin{array}{c}\text { (3) } \\
\text { Cubic Spline } \\
\text { (3 Knots) }\end{array}$ & $\begin{array}{c}\text { (4) } \\
\text { Convex Spec }\end{array}$ \\
\hline Unemp & $\begin{array}{c}-0.00335^{* *} \\
(0.000)\end{array}$ & $\begin{array}{c}-0.00547^{* *} \\
(0.001)\end{array}$ & $\begin{array}{c}-0.00633^{* *} \\
(0.001)\end{array}$ & $\begin{array}{c}-0.00187 * * \\
(0.000)\end{array}$ \\
\hline Linear Spline Term & & $\begin{array}{c}0.00272 * * \\
(0.001)\end{array}$ & & \\
\hline Restricted Cubic Spline Term & & & $\begin{array}{c}0.00349 * * \\
(0.001)\end{array}$ & \\
\hline 1/Unemp & & & & $\begin{array}{c}0.07262 * * \\
(0.019)\end{array}$ \\
\hline Year Effects & Yes & Yes & Yes & Yes \\
\hline State Effects & Yes & Yes & Yes & Yes \\
\hline Observations & 1600 & 1600 & 1600 & 1600 \\
\hline Adj R-Sq & 0.3375 & 0.3399 & 0.3412 & 0.3408 \\
\hline RMSE & 0.0185 & 0.0185 & 0.0185 & 0.0185 \\
\hline AIC & -8243.8104 & -8248.6287 & -8251.7580 & -8250.6875 \\
\hline BIC & -8071.7221 & -8071.1626 & -8074.2920 & -8073.2214 \\
\hline
\end{tabular}

*Significant at $10 \%$ level; **Significant at $5 \%$ level. Note: Each column is a separate regression of real wage inflation (annual change in log wage minus lagged change in log CPI-U) on the variables listed. The wage measure used is hourly wages from CPS-ORG 1982-2013. In column (2) the knot for linear spline term is set at sample average unemployment rate of $6.1 \%$. Three knots for restricted cubic spline in column (3) placed at equally spaced percentiles at 3.7, 5.7, and 9 percent unemployment. Standard errors are clustered at the state level. Estimates are weighted by state-year employment. 
Table 3: Sensitivity of Linear Spline Model to Adjusting Wages

by Different Measures of Inflation

(Dependent Variable: Change in Log Wage minus Lagged Change in Log CPI-U)

\begin{tabular}{lccc}
\hline & $(1)$ & $(2)$ & $(3)$ \\
& CPI-U & Core-CPI & Inflation Expectation \\
\hline Unemp & $\begin{array}{c}-0.00547^{* *} \\
(0.001)\end{array}$ & $\begin{array}{c}-0.00523^{* *} \\
(0.001)\end{array}$ & $\begin{array}{c}-0.00587^{* *} \\
(0.001)\end{array}$ \\
Linear Spline Term & $\begin{array}{c}0.00272^{* *} \\
(0.001)\end{array}$ & $\begin{array}{c}0.00259^{* *} \\
(0.001)\end{array}$ & $\begin{array}{c}0.00303^{* *} \\
(0.001)\end{array}$ \\
& & & \\
Year Effects & Yes & Yes & Yes \\
& & & \\
State Effects & Yes & Yes & Yes \\
\hline Observations & 1600 & 1600 & 1650 \\
Adj R-Sq & 0.3399 & 0.3678 & 0.2603 \\
RMSE & 0.0185 & 0.0185 & 0.0182 \\
AIC & -8248.6287 & -8244.5375 & -8551.5915 \\
BIC & -8071.1626 & -8067.0715 & -8373.1100 \\
\hline
\end{tabular}

*Significant at $10 \%$ level; ${ }^{* *}$ Significant at $5 \%$ level. Note: The dependent variables are annual change in log wage minus: lagged change in log CPI-U (column 1), lagged change in log core-CPI (column 2), one-year ahead inflation excitations from Survey of Professional Forecasters (column 3). The wage measure used is hourly wages from CPS-ORG 1982-2013. One knot for linear spline is set at sample average unemployment rate of $6.1 \%$. Standard errors are clustered at the state level. Estimates are weighted by state-year employment. 
Table 4: Robustness of Linear Spline Model to Inclusion of Additional Covariates (Dependent Variable: Change in Log Wage minus Lagged Change in Log CPI-U)

\begin{tabular}{|c|c|c|c|c|c|}
\hline & (1) & (2) & (3) & (4) & (5) \\
\hline Unemp & $\begin{array}{c}-0.00547^{* *} \\
(0.001)\end{array}$ & $\begin{array}{c}-0.00531^{* *} \\
(0.001)\end{array}$ & $\begin{array}{c}-0.00441^{* *} \\
(0.001)\end{array}$ & $\begin{array}{c}-0.00428^{* *} \\
(0.001)\end{array}$ & $\begin{array}{c}-0.00431^{* *} \\
(0.001)\end{array}$ \\
\hline Linear Spline Term & $\begin{array}{c}0.00272^{* *} \\
(0.001)\end{array}$ & $\begin{array}{c}0.00254^{* *} \\
(0.001)\end{array}$ & $\begin{array}{c}0.00199 * * \\
(0.001)\end{array}$ & $\begin{array}{c}0.00149 * \\
(0.001)\end{array}$ & $\begin{array}{c}0.00151^{*} \\
(0.001)\end{array}$ \\
\hline Year Effects & Yes & Yes & Yes & Yes & Yes \\
\hline State Effects & Yes & Yes & Yes & Yes & Yes \\
\hline State X Trend & No & Yes & Yes & Yes & Yes \\
\hline Demographics & No & No & Yes & Yes & Yes \\
\hline Change in Unemp & No & No & No & Yes & Yes \\
\hline Productivity & No & No & No & No & Yes \\
\hline Observations & 1600 & 1600 & 1600 & 1600 & 1600 \\
\hline Adj R-Sq & 0.3399 & 0.3256 & 0.3405 & 0.3412 & 0.3408 \\
\hline RMSE & 0.0185 & 0.0187 & 0.0185 & 0.0185 & 0.0185 \\
\hline AIC & -8248.6287 & -8268.8347 & -8298.3376 & -8298.1801 & -8296.3578 \\
\hline BIC & -8071.1626 & -8096.7464 & -8088.6050 & -8077.6920 & -8070.4919 \\
\hline \multicolumn{6}{|c|}{$\begin{array}{l}\text { *Significant at } 10 \% \text { level; } * * \text { Significant at } 5 \% \text { level. Note: Each column is a separate regression of real } \\
\text { wage inflation (annual change in log wage minus lagged change in log CPI-U) on the variables listed. The } \\
\text { wage measure used is hourly wages from CPS-ORG 1982-2013. One knot for linear spline is set at sample } \\
\text { average unemployment rate of } 6.1 \% \text {. Standard errors are clustered at the state level. Estimates are } \\
\text { weighted by state-vear emplovment. }\end{array}$} \\
\hline
\end{tabular}


Table 5: Robustness of Linear Spline Model to Alternative Wage Measures (Dependent Variable: Change in Log Wage minus Lagged Change in Log CPI-U)

\begin{tabular}{|c|c|c|c|c|}
\hline & $\begin{array}{c}(1) \\
\text { CPS-ORG } \\
\text { Mean Wage } \\
\end{array}$ & $\begin{array}{c}(2) \\
\text { CPS-ORG } \\
\text { Median Wage } \\
\end{array}$ & $\begin{array}{c}\text { (3) } \\
\text { Avg. Hourly } \\
\text { Eearnings (Manufg.) }\end{array}$ & $\begin{array}{l}(4) \\
\text { Avg. Weekly } \\
\text { Wage }\end{array}$ \\
\hline Unemp & $\begin{array}{c}-0.00514^{* *} \\
(0.001)\end{array}$ & $\begin{array}{c}-0.00657 * * \\
(0.001)\end{array}$ & $\begin{array}{c}-0.00618^{* *} \\
(0.002)\end{array}$ & $\begin{array}{c}-0.00306 * * \\
(0.001)\end{array}$ \\
\hline Linear Spline term & $\begin{array}{c}0.00196 * * \\
(0.001)\end{array}$ & $\begin{array}{c}0.00293 * * \\
(0.001)\end{array}$ & $\begin{array}{c}0.00428 * \\
(0.002)\end{array}$ & $\begin{array}{c}0.00198 * * \\
(0.001)\end{array}$ \\
\hline Year Effects & Yes & Yes & Yes & Yes \\
\hline State Effects & Yes & Yes & Yes & Yes \\
\hline State X Trend & Yes & Yes & Yes & Yes \\
\hline Change in Unemp & Yes & Yes & Yes & Yes \\
\hline Observations & 1600 & 1600 & 1588 & 1600 \\
\hline Adj R-Sq & 0.3269 & 0.3345 & 0.2016 & 0.7877 \\
\hline RMSE & 0.0187 & 0.0199 & 0.0228 & 0.0092 \\
\hline AIC & -8270.1531 & -8060.6031 & -7578.0295 & -10546.7765 \\
\hline $\mathrm{BIC}$ & -8087.3093 & -7877.7593 & -7395.4416 & -10363.9327 \\
\hline
\end{tabular}


Table 6: Robustness of Linear Spline Model to Data Frequency

\begin{tabular}{|c|c|c|c|c|}
\hline & $\begin{array}{c}(1) \\
\text { CPS-ORG } \\
\text { Mean Wage }\end{array}$ & $\begin{array}{c}(2) \\
\text { CPS-ORG } \\
\text { Median Wage }\end{array}$ & $\begin{array}{c}\text { (3) } \\
\text { Avg. Hourly } \\
\text { Earnings (Manufg.) }\end{array}$ & $\begin{array}{l}\text { (4) } \\
\text { Avg. Weekly } \\
\text { Wage }\end{array}$ \\
\hline \multicolumn{5}{|c|}{ Panel A: Quarterly Data (Dependent Variable: 4-quarter Change in Log Real Wage) } \\
\hline Unemp & $\begin{array}{l}-0.00513^{* *} \\
(0.001)\end{array}$ & $\begin{array}{c}-0.00674^{* *} \\
(0.001)\end{array}$ & $\begin{array}{c}-0.00663^{* *} \\
(0.001)\end{array}$ & $\begin{array}{c}-0.00340^{* *} \\
(0.001)\end{array}$ \\
\hline Linear Spline term & $\begin{array}{c}0.00218^{*} \\
(0.001)\end{array}$ & $\begin{array}{c}0.00329 * * \\
(0.001)\end{array}$ & $\begin{array}{c}0.00497 * * \\
(0.001)\end{array}$ & $\begin{array}{c}0.00237 * * \\
(0.001)\end{array}$ \\
\hline $\begin{array}{l}N \\
\text { P-Val on Poolability test }\end{array}$ & $\begin{array}{c}6550 \\
0.9761\end{array}$ & $\begin{array}{c}6550 \\
0.2443\end{array}$ & $\begin{array}{c}6499 \\
0.0000\end{array}$ & $\begin{array}{c}6497 \\
0.0000\end{array}$ \\
\hline \multicolumn{5}{|c|}{ Panel B: Monthly Data (Dependent Variable: 12-month Change in Log Real Wage) } \\
\hline Unemp & $\begin{array}{c}-0.00518^{* *} \\
(0.001)\end{array}$ & $\begin{array}{c}-0.00673^{* *} \\
(0.001)\end{array}$ & $\begin{array}{c}-0.00669^{* *} \\
(0.000)\end{array}$ & $\begin{array}{c}-0.00349 * * \\
(0.000)\end{array}$ \\
\hline Linear Spline term & $\begin{array}{c}0.00217 * \\
(0.001)\end{array}$ & $\begin{array}{c}0.00332 * * \\
(0.001)\end{array}$ & $\begin{array}{c}0.00506^{* *} \\
(0.001)\end{array}$ & $\begin{array}{c}0.00246 * * \\
(0.000)\end{array}$ \\
\hline $\begin{array}{l}N \\
\text { P-Val on Poolability test }\end{array}$ & $\begin{array}{l}19750 \\
0.9989 \\
\end{array}$ & $\begin{array}{l}19750 \\
0.9504 \\
\end{array}$ & $\begin{array}{l}19578 \\
0.0000 \\
\end{array}$ & $\begin{array}{l}19589 \\
0.0000 \\
\end{array}$ \\
\hline Time Effects & Yes & Yes & Yes & Yes \\
\hline State Effects & Yes & Yes & Yes & Yes \\
\hline State X Trend & Yes & Yes & Yes & Yes \\
\hline Change in Unemp & Yes & Yes & Yes & Yes \\
\hline $\begin{array}{l}\text { *Significant at } 10 \% \text { level; * * } \\
\text { inflation (change in log wage } \\
\text { (Panel B) are based on quar } \\
\text { average unemployment rate o } \\
\text { quarter employment. }\end{array}$ & (monthly) d & $\begin{array}{l}\text { l. Note: Each } \\
\text { n log CPI-U) } \\
\text { m } 1981 \text { to } 20\end{array}$ & $\begin{array}{l}\mathrm{nn} \text { is a separate regr } \\
\text { variables listed. Rę } \\
\text { ne knot for linear spl }\end{array}$ & $\begin{array}{l}\text { In of real wage } \\
\text { ions in Panel A } \\
\text { s set at sample } \\
\text { ighted by state- }\end{array}$ \\
\hline
\end{tabular}


Table 7: Seeming Unrelated Regression Estimates of State-Specific Phillips Curve (Dependent Variable: 4-quarter Change in Log Real Average Weekly Wage)

\begin{tabular}{|ccc|}
\hline State & Coefficient on Unemployment Rate & Coefficient on Spline Term \\
\hline AL & $-.003^{* *}$ & $.0035^{* *}$ \\
\hline AK & -.0018 & -.0001 \\
\hline AZ & $-.0029^{*}$ & .0023 \\
\hline AR & $-.0073^{* *}$ & $.0101^{* *}$ \\
\hline CA & $-.0043^{* *}$ & $.0061^{* *}$ \\
\hline CO & $-.0122^{* *}$ & $.016^{* *}$ \\
\hline CT & $-.0035^{* *}$ & $.0036^{*}$ \\
\hline DE & $-.0076^{* *}$ & $.0066^{*}$ \\
FL & $-.0059^{* *}$ & $.0058^{* *}$ \\
\hline GA & $-.0115^{* *}$ & $.0174^{* *}$ \\
\hline HI & $-.0067^{* *}$ & $.0078^{* *}$ \\
\hline ID & .0002 & -.001 \\
\hline IL & $-.0038^{* *}$ & $.0041^{* *}$ \\
\hline IN & $-.0012^{*}$ & .0007 \\
\hline IA & $-.0032^{* *}$ & .0004 \\
\hline KS & -.0016 & -.0005 \\
\hline KY & $-.0075^{* *}$ & $.0085^{* *}$ \\
\hline LA & $-.0062^{* *}$ & $.0053^{* *}$ \\
\hline ME & $-.0028^{*}$ & .0029 \\
\hline MD & $-.0057^{* *}$ & $.0043^{*}$ \\
\hline MA & $-.0107^{* *}$ & $.0128^{* *}$ \\
\hline MI & $-.0016^{* *}$ & $.0022^{* *}$ \\
\hline MN & $-.0079^{* *}$ & $.0089^{* *}$ \\
\hline MS & $-.0035^{* *}$ & $.0035^{* *}$ \\
\hline MO & $-.0039^{* *}$ & $.0036^{* *}$ \\
\hline MT & $-.0044^{* *}$ & $.0054^{* *}$ \\
\hline NE & $-.0036^{*}$ & -.0003 \\
\hline NV & -.0021 & -.0007 \\
\hline NH & $-.0074^{* *}$ & $.006^{* *}$ \\
\hline NJ & $-.0039^{* *}$ & $.0049^{* *}$ \\
\hline NM & $-.0055^{* *}$ & $.0048^{* *}$ \\
\hline NY & -.0015 & .0037 \\
\hline NC & $-.0041^{* *}$ & $.0046^{* *}$ \\
\hline ND & .0022 & .0041 \\
\hline OH & -.0009 & .0009 \\
\hline OK & $-.0052^{* *}$ & $.0048^{* *}$ \\
\hline OR & $-.0057^{* *}$ & $.0063^{* *}$ \\
\hline PA & $-.0015^{*}$ & .0007 \\
\hline RI & $-.0061^{* *}$ & \\
\hline & & .008 \\
\hline
\end{tabular}




\begin{tabular}{ccc}
\hline SC & $-.004 * *$ & $.0046 * *$ \\
SD & $-.0101 * *$ & $.0089 * *$ \\
TN & $-.0019 *$ & .0024 \\
TX & $-.0083^{* *}$ & $.0081^{* *}$ \\
UT & $-.0108 * *$ & $.0152^{* *}$ \\
VT & $-.0069 * *$ & $.0085^{* *}$ \\
VA & $-.0122 * *$ & $.0163 * *$ \\
WA & $-.0097 * *$ & $.009 * *$ \\
WV & $-.0034 * *$ & $.0025 * *$ \\
WI & -.0002 & -.0015 \\
WY & $-.0119 * *$ & $.0097 * *$ \\
\hline
\end{tabular}

*Significant at $10 \%$ level; **Significant at $5 \%$ level. Note: Estimates based on Seemingly Unrelated Regression (SUR) model of real wage inflation (change in log wage minus lagged change in $\log$ CPI-U) on the unemployment rate, its linear spline, and a time trend. Regressions are based on quarterly data from 1981 to 2013. The wage measure is average weekly wages from the QCEW. One knot for linear spline is set at sample average unemployment rate of $6.1 \%$. Estimates based on robust standard errors. 
Table 8: 4-quarter ahead Out-of-Sample Forecast Evaluation of Phillips Curve Models

\begin{tabular}{lccc|ccc|ccc}
\hline & \multicolumn{2}{c|}{ CPS-ORG Mean Wage } & \multicolumn{2}{c|}{ CPS-ORG Median Wage } & \multicolumn{3}{c}{ Avg. Weekly Wage } \\
\hline & $(1)$ & $(2)$ & $(3)$ & $(4)$ & $(5)$ & $(6)$ & $(7)$ & $(8)$ & $(9)$ \\
\hline RMSE & 4.0139 & 3.9252 & 3.93 & 4.107 & 3.9876 & 3.9945 & 2.6065 & 2.5978 & 2.5964 \\
RMSE-NAIVE & 6.3385 & 6.3385 & 6.3385 & 6.4312 & 6.4312 & 6.4312 & 3.627 & 3.627 & 3.627 \\
REL-RMSE & 0.6333 & 0.6193 & 0.62 & 0.6386 & 0.62 & 0.6211 & 0.7186 & 0.7162 & 0.7159 \\
\hline X-Lags (BIC) & 1 & 4 & 4 & 1 & 4 & 4 & 1 & 4 & 4 \\
Y-Lags (BIC) & 4 & 4 & 4 & 4 & 4 & 4 & 4 & 4 & 4 \\
\hline Unemp & No & Yes & Yes & No & Yes & Yes & No & Yes & Yes \\
Spline Term & No & No & Yes & No & No & Yes & No & No & Yes \\
Time Effects & Yes & Yes & Yes & Yes & Yes & Yes & Yes & Yes & Yes \\
& & & & & & & & & \\
State Effects & Yes & Yes & Yes & Yes & Yes & Yes & Yes & Yes & Yes \\
\hline All
\end{tabular}

All estimates obtained by regressing period $t+4$ 4-quarter real wage growth on period $t$ values of: lags of real wage growth (cols (1),(4),(7)) plus lags of unemployment rate (cols (2),(5),(8)) plus lags of spline term (cols (3),(6),(9)). All regressions include state and time effects. Number of lags was chosen using BIC. Forecast evaluation exercise is based on state-level panel data consisting of 116 quarters from 1984:Q1 to 2012:Q4. We start by estimating our model using an initial training sample from 1984:Q1 to 1993:Q4 and using the model to obtain a direct forecast of real wage growth 4-quarters ahead of 1993:Q4, i.e. 1994:Q4. Proceeding recursively, each time expanding the training sample by one quarter, obtaining out-of-sample 4-quarters ahead forecast, and calculating the amount by which our 4-quarter ahead forecast misses actual wage growth for that period, yields out-of-sample forecast error for each quarter of 76 quarters from 1994:Q4 to 2012:Q4 and allows us to calculate Root Mean Squared Forecast Error (RMSE) for a particular model. The naïve 4-quarter ahead forecast is simply the current period's value. 
Table 9: Estimates of Phillips Curve With Short-Term and Long-Term Unemployment

(Dependent Variable: Percent Change in Real Wage)

\begin{tabular}{lcccc}
\hline & $\begin{array}{c}(1) \\
\text { CPS Mean } \\
\text { Hourly Wage } \\
\text { Inflation }\end{array}$ & $\begin{array}{c}\text { CPS Median } \\
\text { Hourly Wage } \\
\text { Inflation }\end{array}$ & $\begin{array}{c}(3) \\
\text { Manuf Avg Hrly } \\
\text { Earnings Inflation }\end{array}$ & $\begin{array}{c}\text { Average Weekly } \\
\text { Wage Inflation }\end{array}$ \\
\hline Short-Term-U & $\begin{array}{c}-0.50275^{* *} \\
(0.143)\end{array}$ & $\begin{array}{c}-0.33471^{* *} \\
(0.153)\end{array}$ & $\begin{array}{c}-0.54355^{* *} \\
(0.263)\end{array}$ & $\begin{array}{c}-0.25436^{* *} \\
(0.120)\end{array}$ \\
& & & & \\
Long-Term-U & -0.00774 & $-0.35296^{* *}$ & 0.01821 & -0.06861 \\
& $(0.137)$ & $(0.127)$ & $(0.603)$ & $(0.107)$ \\
Year Effects & & & & \\
Yes & & Yes & Yes & Yes \\
State Effects & Yes & Yes & Yes & 1000 \\
Observations & 1000 & 1000 & 996 & 0.5973 \\
Adj R-Sq & 0.2811 & 0.2902 & 0.1288 & 1.0465 \\
RMSE & 1.9690 & 2.0263 & 2.7844 & 2897.2080 \\
AIC & 4161.3271 & 4218.6741 & 4834.7501 & 3000.2709 \\
BIC & 4264.3900 & 4321.7370 & 4937.7288 & Yes \\
\hline
\end{tabular}

*Significant at $10 \%$ level; **Significant at $5 \%$ level. Note: Each column is a separate regression of real wage growth (percent annual change in real wage (2000 \$) on the variables listed. Sample period is 1994-2013. Standard errors are clustered at the state level. Estimates are weighted by state-year employment. 
Table 10: Robustness of Phillips Curve Estimates with Short-Term and Long-Term Unemployment

(Dependent Variable: Percent Change in Real Wage)

\begin{tabular}{lccc}
\hline & $(1)$ & $(2)$ & $(3)$ \\
\hline Short-Term-U & $-0.50275^{* *}$ & $-0.50206^{* *}$ & $-0.39073^{*}$ \\
& $(0.143)$ & $(0.185)$ & $(0.213)$ \\
Long-Term-U & & & \\
& -0.00774 & 0.07271 & 0.11380 \\
& $(0.137)$ & $(0.195)$ & $(0.198)$ \\
Year Effects & & Yes & Yes \\
Yes & & Yes & Yes \\
State Effects & Yes & Yes & Yes \\
State X Trend & & & \\
& No & No & Yes \\
Demographics & & 1000 & 1000 \\
Observations & No & 0.2562 & 0.2818 \\
Adj R-Sq & 1000 & 2.0028 & 1.9680 \\
RMSE & 0.2811 & 4139.1808 & 4110.1208 \\
AIC & 1.9690 & 4237.3359 & 4242.6301 \\
BIC & 4161.3271 & 4264.3900 &
\end{tabular}

*Significant at $10 \%$ level; **Significant at $5 \%$ level. Note: Each column is a separate regression real mean hourly wage growth (percent annual change in real mean hourly wage (2000 \$) on the variables listed. Wage measure is from CPS-ORG. Sample period is 1994-2013. Standard errors are clustered at the state level. Estimates are weighted by state-year employment. 